\title{
American STEM Education in Its Global, National, and Linguistic Contexts
}

\author{
Sezai Kocabas ${ }^{1 *}$, Burhan Ozfidan ${ }^{2,3}$, Lynn M. Burlbaw ${ }^{2}$ \\ ${ }^{1}$ Purdue University, USA \\ 2 Texas A\&M University, USA \\ ${ }^{3}$ Prince Sultan University, SAUDI ARABIA
}

Received 8 January 2019 - Revised 21 September 2019 - Accepted 1 October 2019

\begin{abstract}
STEM education was a systematic teaching and/or learning process in the STEM fields and a positive correlation existed between STEM education, and the economic prosperity and power of a nation in the globalized world. In recent years, rising concerns have emerged about American STEM education. Many stakeholders wondered that whether the nation has enough well-qualified STEM students, teachers and workforce to maintain its current competitive edge. This study sought to answer those questions, presenting a unique view about the concerns. This study, besides, summarized selected major legislation which affected STEM Education in the United States. The results of the study showed that American students in elementary and secondary schools have relatively mediocre scores compared with their international peers (especially Asians), although they performed better than earlier American cohorts in science and mathematics. The quality of STEM teachers also led to concerns. The lowest certification rate of teachers was found in science and mathematics, and approximately half of the teachers did not have a degree in the subject that they teach. Lastly, this study revealed that students should learn the requisite new patterns of language and expression only through opportunity for and engagement in STEM disciplinary practices.
\end{abstract}

Keywords: STEM, American STEM education, science, mathematics, success of students, stakeholders, diversity, language

\section{INTRODUCTION}

Science, technology, engineering and mathematics (STEM) education, and economic prosperity and a nation's power are highly correlated in the globalized world (Machi, 2009). The United States is one of the world's most outstanding nations, and the nation has maintained its current position through science, technology, engineering and mathematics (Ozfidan \& de Miranda, 2018). However, a concern is growing that the United States does not currently have good standing in STEM education. This situation could lead the nation to fall behind its international counterparts including China in an increasingly competitive global market. Therefore, the condition of STEM education in the United States has become more crucial now than in the past. In this study, we presented a useful context about American STEM education based on the research question. Then, we summarized selected major legislation which affected American STEM Education. We also investigated that learning STEM subjects involves extending students' meaning-making potential through language. To engage effectively with disciplinary learning, students expand their repertoires of language skills developed during the early years of schooling and learn to recognize how language is used to make meaning, discuss ideas, present knowledge, construe value, and create specialized texts across disciplines.

(c) 2020 by the authors; licensee Modestum Ltd., UK. This article is an open access article distributed under the terms and conditions of the Creative Commons Attribution License (http://creativecommons.org/licenses/by/4.0/). \skocabas@purdue.edu (*Correspondence) $\square$ b.ozfidan@tamu.edu bozfidan@psu.edu.sa 


\section{Contribution of this paper to the literature}

- Recently, there are a few studies that investigated American STEM education in its national and global perspective. Hence, this study investigated changes of STEM education achievement in the United States.

- This study presented a holistic perspective of American STEM education in increasingly globalized world. Therefore, the study would contribute to advance teaching and learning of STEM education in the United States.

- Learning STEM subjects involves extending students' meaning-making potential through language. This study would contribute the role of language in STEM learning.

We examined a question related to this condition: Does American STEM education create well-qualified and enough numbers of STEM students, teachers and members of the workforce to maintain a competitive edge in the globalized world?

\section{WHAT IS STEM AND STEM EDUCATION}

Before the introduction of current acronym, "STEM", the National Science Foundation (NSF) was using an acronym of "SMET" that referred to four distinct fields; science, mathematics, engineering and technology (Sanders, 2009). In recent years, STEM has been a buzzword among American stakeholders (Breiner, Harkness, Johnson, \& Koehler, 2012). Despite its buzzword status, an ambiguity exists in the definition of STEM (Madden, Beyers, \& O'Brien, 2016). The ambiguity has led to different definitions and occupational applications among stakeholders across the United States (Ntemngwa \& Oliver, 2018), because several programs within various scientific communities have utilized it (Breiner, et al., 2012). Thus, the definition differs depending on who has employed it (Sanders, 2009).

As a term, STEM has gained a remarkable ground since 2001 (Breiner, et al., 2012). Today, quite a few occupations in STEM and non-STEM fields have required more knowledge of STEM (Gonzales \& Kuenzi, 2012), which is significant for individual's life because STEM skills are used in manufacturing smarter products to grow the economy (NSTC, 2013). Hence, the National Research Council (NRC) defines STEM as "cultural achievements that reflect people's humanity, power of economy and constitute fundamental aspects of our lives as citizens, workers, consumers, and parents" (NRC, 2011, p. 3).

STEM education has gained attendance and has defended its own sovereign territory for a century (Sanders, 2009), so it is now widely used by institutions or individuals in the STEM fields (Bybee, 2010). Despite the wide use, "STEM education" is often used interchangeably with the term "STEM" in the literature. However, STEM and STEM education are two different terms having two different meanings, because STEM education means a lot more than the four-letter acronym of STEM (Sanders, 2009). Some argue that STEM education explains only science and mathematics; others believe that STEM education is a variety of activities that include more inquiry and projectbased teaching strategies instead of traditional lecture-based ones (Breiner, et al., 2012). From a broader perspective, STEM education could be described as a systematic teaching and/or learning process in the STEM fields (Ntemngwa \& Oliver, 2018). Consequently, no certain operational definition exists because it is variously perceived by the stakeholders; therefore, focusing on the goals of STEM education is needed to best understand the concept.

STEM education aims to improve students' science and mathematics scores and prepare them for their future education and careers (Becker \& Park, 2011 S1). STEM education, additionally, aims to have more students graduating from the STEM fields (Breiner, et al., 2012). Therefore, almost all stakeholders agree that STEM education is about creating more qualified teachers, students and workforce (Breiner, et al., 2012) to maintain or to gain a competitive edge across the global (Machi, 2009) That is because STEM education would instill a passion for inquiry, discovery and the application of gained knowledge to new situations (Tananbaum, 2016).

It is not incorrect to state that STEM education merely focuses on how the best practices would be implemented in the STEM fields (Mills, 2017), and STEM education has begun to be stated in more an integrative context in recent years (Madden, Beyers, \& O'Brien, 2016). Sanders (2009) explained integrated STEM education as the approaches that "explore teaching and learning between/among any two or more of the STEM subject areas, and/or between a STEM subject and one or more other school subjects" (p. 21). In other worlds, it is the interdisciplinary approach that tries to meld two or more STEM subjects into a single project (Ntemngwa \& Oliver, 2018). Another definition is that integrative STEM education is a means to increase a student's understanding of a course, a unit or a lesson by integrating two or more STEM fields (Brown et al., 2017). In light of these definitions, the major goal is to enhance student learning (Tananbaum, 2016) and to acquire several skills like problem solving by increasing motivation via project-based learning in a more student-centered education (Laboy-Rush, 2011).

Sander's (2009) definition comprises other non-STEM subjects to integrate them to the STEM fields because any development in STEM fields cannot be related to the social/behavioral sciences. Therefore, some stakeholders like 
the NSF define STEM fields in a broader perspective that includes the four fields of science, mathematics, engineering and technology as well as social/behavioral sciences like psychology, economics, sociology and political science (Green, 2007), although some agencies have a narrower perspective.

\section{AMERICAN STEM EDUCATION}

Science, Technology, Engineering and Mathematics (STEM) have been crucial areas in the educational curriculum for United States to maintain its dominant position since the launch of the Soviet Union's Sputnik satellite in 1957 because a strong connection was seen to exist among a nation's welfare and power and STEM education (Gonzalez \& Kuenzi, 2012). Even if they are interested in non-STEM subjects, workers in the job market should understand STEM subjects that are basic to their daily live (Mullis \& Martin, 2017). Thus, as Gonzalez and Kuenzi, (2012) noted "today the economic and social benefits of scientific thinking and STEM education are widely believed to have broad application for workers in both STEM and non-STEM occupations" (p. 1).

In this century, a wide range of collaborative studies of various fields have said that a broad range of innovations and suggestions to solve world problems are brought to market by the STEM workforce (Mullis \& Martin, 2017). A deficiency in any STEM field has caused irreversible damages affecting all related fields and producing a detrimental domino effect (Machi, 2009). Hence, governments the world over have allocated more funds from their budgets to STEM education to improve students' scores in science and mathematics and to make students ready for their future educations or careers (Becker \& Park, 2011) by increasing student motivation through project-based learning (Laboy-Rush, 2011). In other words, by giving more appropriations to STEM education, governments aimed to develop a qualified STEM workforce that is expected to help their countries to gain a competitive edge in the globalized world.

Many American stakeholders had several concerns about American STEM education. The most recent concern was whether the nation has enough well-qualified STEM students, teachers and workforce to maintain a competitive edge (Kuenzi, Matthews, \& Mangan, 2006). To determine this, the condition of STEM education in the United States must be evaluated to have a view on this the concern. American Stem education, hence, evaluated from different perspectives. Because characterizing of the condition of STEM education in the United States was difficult through a single fact or statistic (Gonzalez \& Kuenzi, 2012).

\section{The Performance of American Students from a Global Perspective}

American students were expected to achieve high scores on international achievement tests, because the United States had one of the highest GDPs per capita in the world, and investment in education (especially STEM education) was directly proportional to GDP per capita. However, students' science and mathematics scores in the United States did not perform well in comparison with some of their peers especially those from Asian countries. Thus, the performance of American students versus their peers in international assessments was relatively mediocre despite of the wealth of their nation.

The lower scores of American students created a disadvantageous situation and negatively impacted the ability of the United States to remain competitive in the world. In 2010, then Secretary of Education, Arne Duncan, speaking at the annual meeting of the Association of American Publishers, noted the threat to the long-term economic prosperity of the United States of the low achievement of American students. Calling for reform, he said "The urgency has never been greater. Our children and our future are at risk, so let us together do the difficult but necessary things our schools demand. We have a moral and economic imperative that requires us to act" (Duncan, 2010). One of the most critical elements of his concern was whether the nation has enough well-qualified STEM students to compete in the world.

To determine the current situation, we presented evidence about previous and the most recent assessments of the performance of American student at international level in the following section. Three international assessments administered periodically. These were Trends in International Mathematics and Science Study (TIMSS), Program for International Student Assessment (PISA), and Progress in International Reading Literacy Study (PIRLS). However, only TIMSS and PISA explored in this study, because PIRLS measured reading achievement.

\section{TIMSS}

The most recent TIMSS cycle was administered in 2015 for 4, 8 and 12 grade students in Science and Mathematics. (NCES, n.d. a). The results of the assessment were published in November 2016.

On the TIMSS mathematics assessment (Appendix A), the average score increased by 21 points 518 to 539 for the fourth-grade level (despite a 2-point decrease from 2011 to 2015) and by 26 points 492 to 518 for the eighthgrade level since the first year of administration in 1995. In addition, we found a stable increase in high and above level students for both grades in mathematics over the 20-year period. 
In the last cycle that was in 2015, Singapore, Hong Kong, South Korea, Chinese Taipei and Japan had the top average scores, which were 54 points higher at the fourth-grade level and 68 points higher at the eighth-grade level compared to the scores of American students. The average score at fourth-grade level of the United States was significantly higher than the scores of 26 education systems, while the scores of 9 systems were significantly higher than US average scores at the .05 level. The average score at the eighth-grade level of the United States was significantly higher than the scores of 19 education systems, while 6 systems were significantly higher than the US average scores at the $\mathrm{p}=.05$ level. Additionally, 37\% of American students at the eighth-grade level performed at the high and above levels, and six educational systems had significantly higher percentages at that level. At the fourth-grade level, $47 \%$ of American studies reached the high and above levels on mathematics, and eight educational systems had significantly higher percentages at that level (Mullis, Martin, Foy, \& Hooper, 2016).

In the TIMSS Science assessment (Appendix B), the average score increased by 4 points 542 to 546 for fourthgrade students and by 17 points 513 to 530 for eighth-grade students since 1995 . In addition, high and above level of students slightly decreased for both grades in science over the 20-year period.

In the last cycle, the top performing countries in mathematics including as well as the Russian Federation had top average scores that were 9 points higher at the fourth-grade level and 14 points higher than at eighth-grade level when compared with the scores of American scores, which were 546 at grade 4 and 530 at grade 8 . The average score at the eighth-grade level of American students was significantly higher than the scores of 20 educational systems, while 7 systems were significantly higher than US average scores at the .05 level. The average score of American students the fourth-grade level was significantly higher than the scores of 30 educational systems, while 7 systems were significantly higher than US average scores at the .05 level. Additionally, $43 \%$ of American students at eighth-grade level performed at the high and above levels; eight educational systems had significantly higher percentages at that level than the United States, while $51 \%$ of American fourth-graders reached the high and above levels on science; six education systems had significantly higher percentages at that level than the United States (Martin, Mullis, Foy, \& Hooper, 2016).

\section{PISA}

The most recent PISA cycle was administered in 2015 for 15-year-old students. More than 500.000 students participated in this assessment cycle, representing a population of 28 million students in 72 countries and economies (OECD, n. d. a). Country participation in the PISA across the world increased by about $70 \%$ rising from 20.3\% to 33.95\% since 2000 (Lockheed, 2015). Students were assessed in three core subjects (science, mathematics, reading) and optional subjects (collaborative problem solving and financial literacy) (OECD, n.d. a), and the dominant subject was science in 2015 like previous cycle in 2006 (Hopstock \& Pelczar, 2011). The test was designed to take two hours; one hour for science and one hour for other two core subjects (OECD, 2017). The results of the assessment were published in December 2016 (OECD, n.d. a).

With respect to the United States on the PISA mathematics assessment, the average score decreased by 13 points from the 2003 to the 2015 administration. The scores significantly decreased by 17 points from 487 to 470 between 2009 and 2015 and by 11 points 481 to 470 between 2012 to 2015 with no other significant differences among the years. The average score in science increased by 7 points 489 to 496 between 2006 and 2015, but the average score decreased after 2009. The scores in 2012 and 2015 were respectively 497 and 496, which were lower than they were in 2009 when the score peaked at 502 (Appendix C).

In the last cycle that was shown in Appendix D, the top performers countries in mathematics (Singapore, HongKong, Macau-China, Chinese Taipei, Japan and B.S.J.C - China) had top average scores at least 61 points higher than US average score of 470 . The students in the countries of Singapore, Japan. Estonia, Chinese Taipei, Finland and Macau-China scored at least 33 points higher than the average score of their American peers in science, which was 496 (Appendix E). The OECD average score on mathematics in the last cycle was 490, but for the United States the score was 470; 20 points lower than average score. Just more than half of the participant countries or economies (37) had a significantly higher score than United States at the .05 level. The US average score in science was 496, which was just more than the OECD average score of 493 . Nineteen countries including Chinese provinces had significantly a higher score than United States at the .05 level. Additionally, 20.3\% of American students performed below level 2, while $8.5 \%$ of the students achieved at level 5 and above in science literacy. There were 15 countries that a had a significantly higher percentage of students at level 5 and above at the .05 level. In mathematics literacy, 29.4\% American students performed below level 2, while 5.9\% of the students had an achievement at level 5 and above (Kastberg, Chan, \& Murray, 2016). There were 38 countries that had a significantly higher percentage of students at level 5 and above at the .05 level. 


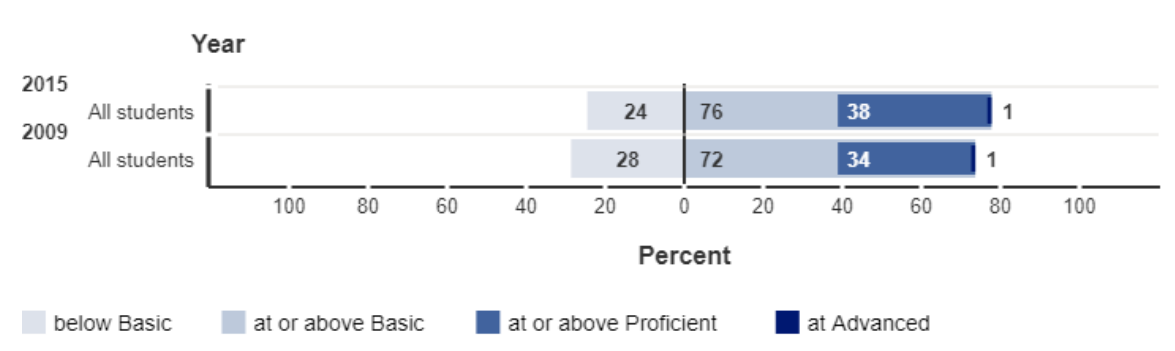

NOTE: Some apparent differences between estimates may not be statistically significant.

SOURCE: U.S. Department of Education, Institute of Education Sciences, National Center for Education Statistics, National Assessment of Educational Progress (NAEP), 2009 and 2015 Science Assessments.

Figure 1. Achievement-level results for fourth-grade students assessed in NAEP science: 2009 and 2015

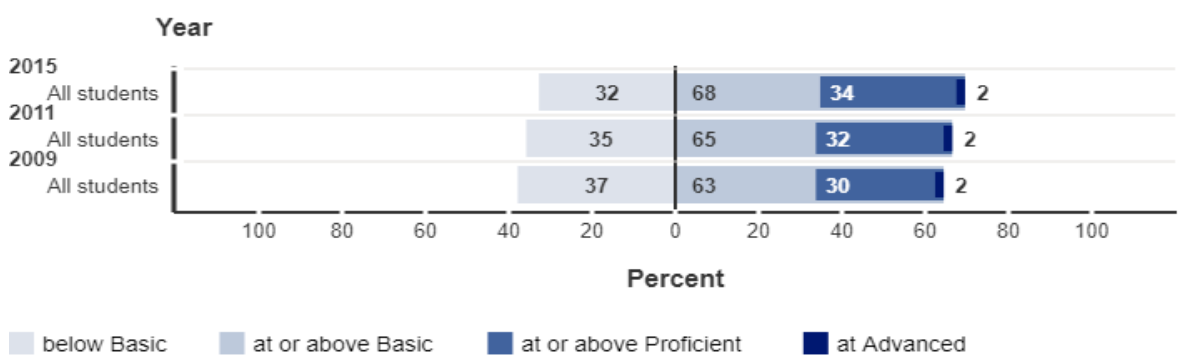

NOTE: Some apparent differences between estimates may not be statistically significant.

SOURCE: U.S. Department of Education, Institute of Education Sciences, National Center for Education Statistics, National Assessment of Educational Progress (NAEP), 2009, 2011, and 2015 Science Assessments

Figure 2. Achievement-level results for eighth-grade students assessed in NAEP science: 2009 and 2015

\section{The Performance of American Students from a National Perspective}

The growing concern about academic achievement trend in science and mathematics for US students should be analyzed from a distinct perspective rather than as just another part of the concern for the relatively lower achievement of US students compared to their several counterparts over the world. To do so, evidence about previous and current American students must be placed in historic context. The National Assessment of Academic Progress (NAEP) was the most appropriate assessment to track the changing trends in the subjects. The most recent science assessment was administered in 2015 for the fourth and eighth grades. The assessment had 115,400 students from 7,650 schools for fourth grade and 110,900 students from 6050 schools for eighth grade. Note that science assessment in 2011 had only eighth grade students because of linking effort with TIMSS.

Figures 1 and 2 demonstrated the available results for both grades 2009 to 2015. The six years witnessed a 4point increase on average scores; 150 to 154 for both grades. The percentage of both grades at the advanced level did not change with just $1 \%$ and $2 \%$ of fourth and eighth grade students respectively over the time. Additionally, there was a slight decrease for both grades at the below basic level. In the most recent assessment in 2015, more than one third of fourth and eighth grade students had a score of at or above proficient level; 38\% and 34\% respectively. In $2015,24 \%$ and $32 \%$ of the sample for fourth and eighth grade students respectively performed below the basic level.

The most recent long-term NAEP assessment was conducted in 2012. From 1973 to 2012, the average math scores of students at ages 9 and 13 increased significantly while those at age 17 did not change significantly. Thus, the average score at age 9 was 25 points higher than in 1973, whereas the average score was 19 points higher for the students at age 13 (NCES, 2013).

The most recent main mathematics assessment was administered as digitally based between January and March 2017 and reported in April 2018. The assessment had 149,400 students from 7,480 schools for grade four and 144,900 students from 6,500 schools for grade eight. Figures 3 and 4 demonstrated the available results for both grades from 2003 to 2017. In the fourteen years, there was a 5-point increase on the average scores; 235 to 240 for fourth grade and 278 to 283 for eighth grade. The percentage of fourth and eighth grade students at the advanced level increased exactly twice with a slight decrease for both grades at the below basic level. In the most recent assessment in 2017, more than one third of the both grades of students scored at or above proficient level; $40 \%$ and $34 \%$ respectively. In $2017,20 \%$ and $30 \%$ of the sample for fourth and eighth grades respectively performed below the basic level in 2017. 


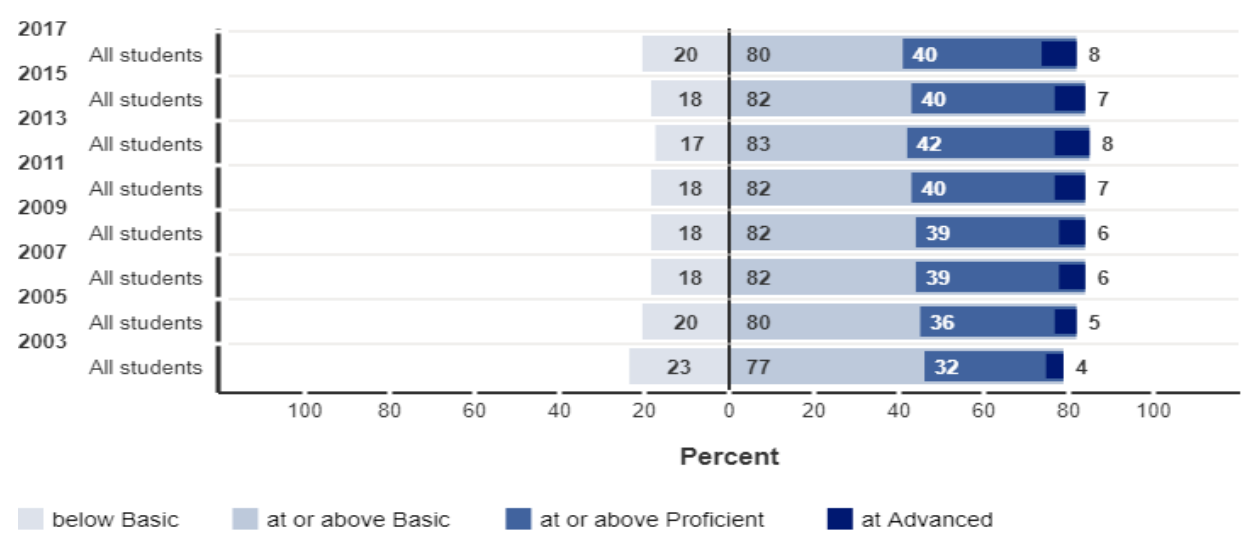

NOTE: Some apparent differences between estimates may not be statistically significant.

SOURCE: U.S. Department of Education, Institute of Education Sciences, National Center for Education Statistics, National

Assessment of Educational Progress (NAEP), 2003, 2005, 2007, 2009, 2011, 2013, 2015, and 2017 Mathematics Assessments.

Figure 3. Achievement-level results for fourth-grade students assessed in NAEP mathematics: 2003, 2005, 2007, 2009, 2011, 2013, 2015 and 2017

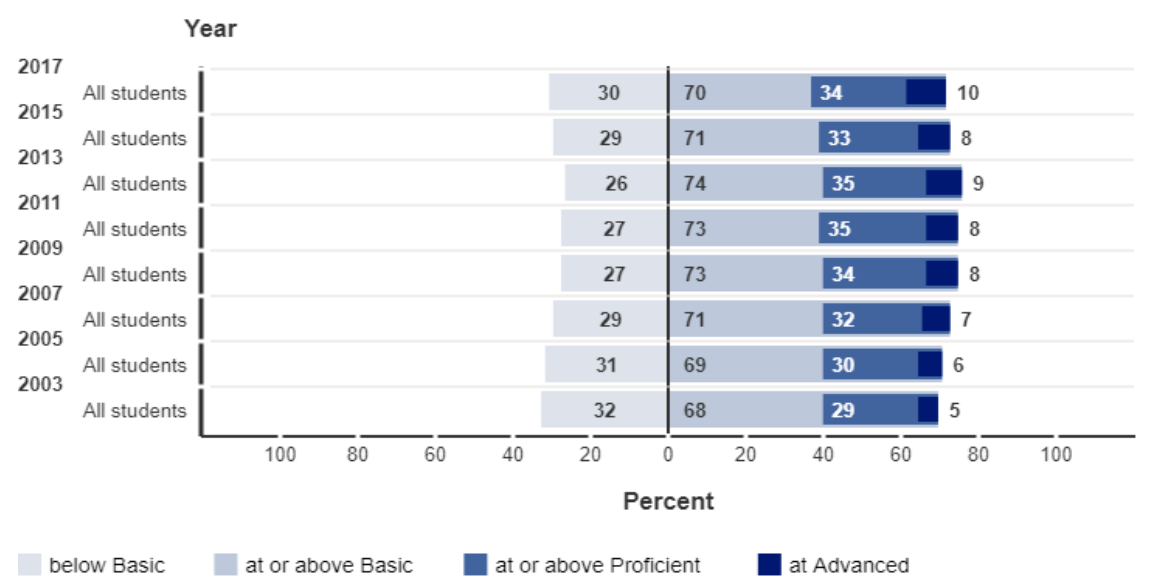

NOTE: Some apparent differences between estimates may not be statistically significant.

SOURCE: U.S. Department of Education, Institute of Education Sciences, National Center for Education Statistics, National

Assessment of Educational Progress (NAEP), 2003, 2005, 2007, 2009, 2011, 2013, 2015, and 2017 Mathematics Assessments

Figure 4. Achievement-level results for eighth-grade students assessed in NAEP mathematics: 2003, 2005, 2007, 2009, 2011, 2013, 2015 and 2017

\section{Teacher Quality in the United States}

Many policymakers, educators and other stakeholders had growing concern about how the United States can keep it current economic dominant position given the mediocre performance of its educational systems compared with the rest of the world (Killewald \& Xie, 2013). As Francis Eberle, who was executive director of the National Science Teachers Association from 2008 to 2012, explained it; "other countries are investing, and we can see their progress. Do we want to be average?" (Toppo, 2008). Some stakeholders argued that the US teaching force is a source of the insufficient performance of students on science and mathematics in the national and international assessments (Kuenzi, Matthews, \& Mangan, 2006).

Indeed, prior research has shown an association between teacher education/certification and student outcomes (Hill \& Stearns, 2015). In other words, whether teachers hold regular or standard professional certification was a crucial issue for student achievement in American education. Thus, analyzing subject-based teacher certification, including those in science and mathematics, could provide deeper information. Holding a certificate in the field that is taught in the classroom has been found to be important, because recent research has highlighted that holding a major/certificate in the subject taught in class had a positive relationship with student achievement (Allen, 2005). Thus, this section presented some evidence of subject-based teacher certification to gain a perspective about quality of teachers in the United States. 
Table 1. Total number of public school teachers and percentage distribution of public school teachers, by type of teaching certificate, $2015-16$

\begin{tabular}{|c|c|c|c|c|}
\hline \multicolumn{5}{|c|}{$\begin{array}{l}\text { Type of teaching certificate } \\
\text { Total number of teachers } 3,827,1000\end{array}$} \\
\hline $\begin{array}{l}\text { Regular or standard state certificate / } \\
\text { advanced professional certificate }\end{array}$ & $\begin{array}{l}\text { Probationary } \\
\text { certificate }\end{array}$ & $\begin{array}{c}\text { Temporary or } \\
\text { provisional certificate }\end{array}$ & $\begin{array}{l}\text { Waiver or emergency } \\
\text { certificate }\end{array}$ & No certification \\
\hline $90.3 \%$ & $3.1 \%$ & $4.3 \%$ & $0.9 \%$ & $1.4 \%$ \\
\hline
\end{tabular}

The School and Staffing Survey (SASS) was a national survey designed to collect data about educational components such as such as teachers, principals and libraries from public and private schools at elementary and secondary level (Baldi, Warner-Griffin, \& Tadler, 2015). The SASS was being conducted biennially by the NCES from 1987 to 2011. After which, a new survey, called the National Teacher and Principal Survey (NTPS) (NSB, 2018a), was utilized. The main goal for the NTPS was to provide a more flexible and timely survey that was integrated with other Department of Education methods (NCES, n.d. b). Although the new survey included the same core topics as SASS, it also included newer topics like the use of information technologies by teachers in the classroom (NSB, 2018a). The following paragraphs provided some statistical information about teacher certification from both surveys.

The most recent data was available from NTPS is 2015-16. From a general perspective, $90.3 \%$ of $3.827,100$ US teachers in all fields have regular or standard professional state certification while $1.4 \%$ of all teachers work without the certification (Table 1). So, it could be stated that most US teachers held teaching certificate during the 2015-16 school year.

Additionally, statistical information about subject-based teacher certification in English, science and mathematics should be examined. The most recent subject-based information based on the SASS was in 2011-12. The most recent SASS results illustrated that teacher certification rates differ by subjects (Appendixes F \& G). In the public middle schools, the percentage of all teachers holding certificates in English, mathematics and science were $56.8 \%, 52.9 \%$ and 56.8\%. In English, mathematics and science $46.1 \%, 28.1 \%$, and $44.9 \%$ of the teachers respectively held a major in their main assignment while $53.7 \%, 71.9 \%$ and $55.1 \%$ of teachers in these subjects respectively lacked a major in their main assignment. However, the rate of having certification in public high schools was higher than the rate in middle grades in the three subjects as $82.1 \%$ of English teachers had certification, $80.9 \%$ of mathematics teachers had certification and $85.7 \%$ of science teachers had certifications. Teachers holding a major in their main assignment was $79.4 \%$ for English, $70.1 \%$ in mathematics and $79.7 \%$ in science while $20.6 \%$, $29.9 \%$ and $20.3 \%$ of teachers respectively lacked a major in their main assignment.

\section{Labor Supply in STEM Fields}

After the 2007-2008 world economic crisis, economic balances changed fast, and Asian countries with the leadership of China have been gaining more ground in the global economy. By 2030, Asian economies were projected to have $40 \%$ of the global GDP approximately and half of that was from the Chinese economy (Fensom, 2017). GDP growth slowed significantly in China falling from a $14.2 \%$ yearly increase in GDP in 2007 to $6.9 \%$ in the ten years between 2007 to 2017 (Morrison, 2018). In fact, the slowdown is result of the Chinese policy to rebalance the growth model (Fensom, 2017) to avoid a middle-income trap (Morrison, 2018).

Two ways exist to avoid this trap: technological innovation and industrial upgrading (Hutchinson \& Das, 2016). Thus, innovation has been a top priority in certain sectors in the Chinese economic plan (Morrison, 2018). For example, China is gaining significant ground in the Internet-based economy and in some manufacturing industries (Hutchinson \& Das, 2016) as well as in electrical engineering and computing (Machi, 2009). The Chinese efforts to avoid the middle-income trap have led to concerns in the United States that China eventually aims to dominate global market by decreasing reliance on foreign technology, U.S. Trade Representative Robert Lighthizer has described this as "a very, very serious challenge, not just to US, but to Europe, Japan and the global trading system" (Morrison, 2018, p. 48).

In the global world, the STEM workforce provides innovations, which separate developed nations from developing nations (Machi, 2009); hence, the Chinese economic plan is closely associated with STEM education. Chinese policies under the plan are a source of rising concern about STEM education in the United States. The stakeholders related to STEM subjects agree that any deficiency in US STEM education either has either resulted in or will result in workforce shortages and that this problem has impacted US global economic competitiveness and national security negatively (Gonzales \& Kuenzi, 2012). Therefore, data about US higher education should be examined to see whether the United States has either a high quality or a sufficient number of members of the STEM workforce. 


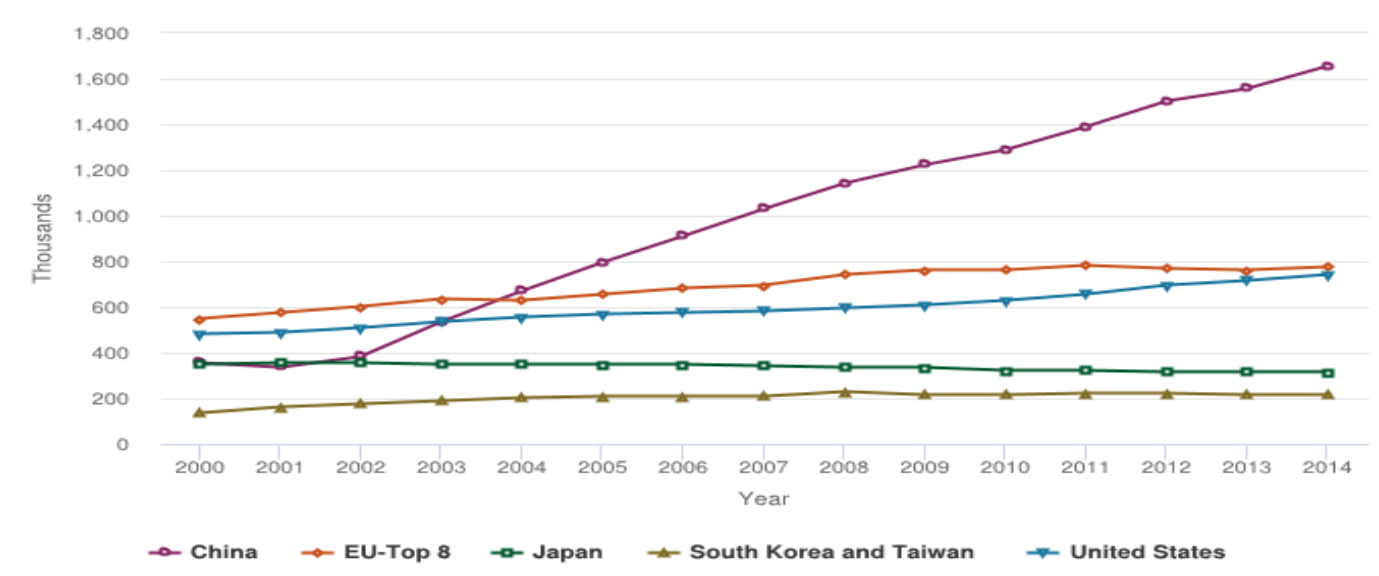

Note(s): EU-Top 8 is the eight European Union countries with the most bachelor's degree awards in 2014: UK, Germany, France, Poland, Italy, Spain, Romania, and the Netherlands.

Indicators 2018 : First University Degrees in S\&E Fields, Chapter 2

Figure 5. Bachelor's degree awards in S\&E fields, by selected region, country or economy, 2000, 2014. Source: NSB. (2018b)

Although a popular view is that American top students are reluctant to enter upon a scientific career (Benderly, 2010), statistical data about the pursuit of higher education in STEM subjects would serve as an indicator for condition of the labor supply. This may be examined in terms of degree enrollment and degree awarded statistics.

Enrollment in institutions of higher education in the United States significantly increased from 17.5 million to 20.0 million in the ten years from 2005 to 2015 (Hussar \& Bailey, 2017). However, the increase differs between the undergraduate and graduate levels. There was a $14 \%$ an increase in enrollment from 15 million to 17 million for total baccalaureate enrollment with a peak of 18.3 million in 2010 (Hussar \& Bailey, 2017) whereas the enrollment rate in post-baccalaureate degree experienced 17\% growth increasing from 2.5 million to 2.9 million in the same ten-year period (Snyder, de Brey, \& Dillow, 2018).

From the Science and Engineering (S\&E) perspective, $45 \%$ of freshmen intended to study S\&E subjects in which biological and agricultural sciences and engineering are rising majors (NSB, 2018a). Almost 668,000 graduate students were enrolled in S\&E majors in 2015, and graduate students are becoming more interested in computer sciences, mathematics and statistics, medical sciences, and engineering with respect to previous years (NSB, 2018a).

The number of undergraduate (bachelor's) and graduate (master's and doctorate) degrees in S\&E and non-S\&E fields awarded by US higher institutions increased during the period from 2000 to 2015 . These increases were $50 \%$ in baccalaureate, $59 \%$ in master's and $48 \%$ in doctorate degrees (Hussar \& Bailey 2017).

In S\&E fields, more than 7.5 million students are globally awarded a bachelor's degree (NSB, 2018b). The number of awarded bachelor's degrees in S\&E by US higher institutions increased by almost $50 \%$ rising from 483,000 to 742,000 , which is almost $10 \%$ of all awarded bachelor's degree at the global level. However, the number of Chinese awarded degrees more than quadrupled during the same period, growing from 359,000 to more than $1,600,000$, which is just less than $25 \%$ in S\&E fields over the world (See Figure 5). Additionally, the proportion of S\&E fields of all bachelor's degree in China is $48 \%$, while it is $39 \%$ in the United States (NSB, 2018b). Thus, China would seem to have a competitive edge against the United States.

The number of awarded S\&E doctoral degrees in United States had a trend similar to that of bachelor's degree during the 2000 to 2014 period, rising from 26,000 to 40,000. China had about same number of graduates awarded doctorate degrees in S\&E fields as the United States in 2014. In 2000, the United States $(24,000)$ had three times more graduates than China did $(8,000)$ in 2000 . Additionally, just less than $40 \%$ of doctorate recipients in S\&E fields in the United States were temporary visa holders (Figure 6).

Recipients of post-baccalaureate degrees are seen as bringing advances in research that will lead to innovations profoundly impacting a nation's competitive edge in the global world. The dramatic increase of baccalaureate and post baccalaureate degrees conferred in China has been seen as a critical factor income by rebalancing the country's scientific and technological capabilities with the United States. The citizens of China and the United States publish the most S\&E research papers. In 2014, China has 426,000 research articles rising from 87,000 in 2000 while the United States had 409,000 articles in 2014 rising from 22,000 in 2000 (NSB, 2018b). These results provide a perspective regarding on how China has gained ground and is gaining a competitive edge against the United States in the global world. 


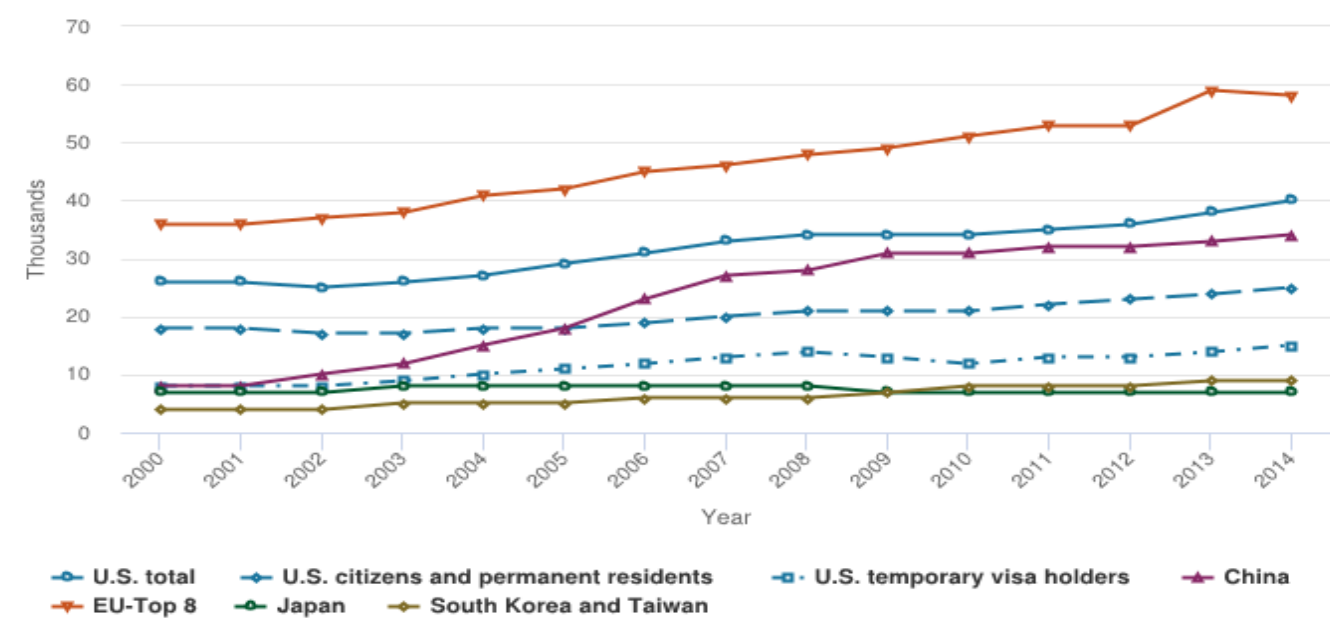

Note(s): EU-Top 8 is the eight European Union countries with the most doctoral degree awards in 2014: Germany, UK, France, Spain, Italy, Portugal, Sweden, and Romania.

Indicators 2018 : International Comparison of S\&E Doctoral Degrees, Chapter 2.

Figure 6. Doctoral degree awards in S\&E fields, by selected region, country or economy, 2000, 2014. Source: NSB, 2018b

\section{ROLE OF LANGUAGE AND CULTURE IN STEM LEARNING}

Language is simultaneously a cognitive ability and a cultural resource that children first learn to draw on in their homes and communities. As they interact with caregivers in the early years, the language they develop enables them to participate in the community's cultural practices and learn its ways of being, as well as to organize and make sense of their complex worlds (Aydin, \& Cinkaya, 2018). For example, children begin to learn about cause and effect in everyday contexts as they experience and talk about conditions, purposes, and reasons (Ozfidan \& Toprak, 2019). Their understanding of cause and effect develops along with the language through which causal relationships are expressed. Through many such interactions, they learn both the language and values of their culture and are introduced to concepts relevant for later STEM learning. For some children, this development occurs in more than one language.

To learn STEM subjects, students should learn the requisite new patterns of language and expression only through opportunity for and engagement in STEM disciplinary practices. The developmental pathways available to individual learners in STEM classrooms are influenced by the opportunities they are offered to participate in the practices and discourses of STEM fields (Green, 2007). Learning STEM subjects requires support for learning to use the discourse patterns through which the knowledge in each subject area is presented and engaged with. All children require such support, including those learning in their mother tongues or first language (Ozfidan \& Burlbaw, 2016). For ELs, success often hinges on engaging in classroom and out-of-school experiences that encourage them to draw on the languages and multicompetences they already control and to connect new concepts with the knowledge they bring from their homes and communities (ESSA, 2018). When allowed to interact in varied ways to build from what they already know and to develop new technical knowledge at school, ELs can learn STEM content and practices while simultaneously building their proficiency in English beyond STEM.

\section{Science and Language Instructional Shifts with English Learners}

Recent years have witnessed parallel shifts toward promoting the social and sense-making nature of both science learning and second language development. In science education, whereas traditional views focused on individual learners' mastery of discrete elements of science content, contemporary views emphasize that students engage in science and engineering practices (e.g., developing models, arguing from evidence, constructing explanations) to make sense of the world around them (National Association of School Psychologists, 2018). Because this approach to science learning involves using and applying knowledge for a particular purpose, it has been referred to as knowledge-in-use (Ilhan, Ozfidan, \& Yilmaz, 2019). In second-language development, whereas earlier theories saw it as the accumulation of discrete elements of vocabulary (lexicon) and grammar (syntax) to be internalized by learners, more recent thinking has taken a sociocultural turn, viewing language as a set of dynamic meaning-making practices learned through participation in social contexts (NCES, 2013). Because this approach to 
language learning involves using language for a particular purpose, it has been referred to as language-inuse (Becker \& Park, 2011). Knowledge-in-use in science education and language-in-use in second-language development complement each other, such that science instructional shifts promote language learning with ELs, while language instructional shifts promote science learning with ELs. Recognizing science and language instructional shifts as mutually supportive can lead to better and more coherent instructional approaches that promote both science and language learning with all students, especially ELs.

\section{SELECTED MAJOR LEGISLATION AFFECTING US STEM EDUCATION}

Several laws have been authorized to obtain quality education in the United States. Although several acts have specifically focused on STEM education, major acts about elementary and secondary education have created an infrastructure for the development of more specific acts for STEM education. Thus, brief information is provided below about the acts related to elementary and secondary education.

One of them, the Elementary and Secondary Education Act (ESEA), was signed by President Lyndon B. Johnson in 1965 (P.L. 89-10). He evaluated the ESEA as a national goal of full educational opportunity (ESSA 2018), and the president considered the act as a part of his War on Poverty (McLaughlin, 1975). Hence, the act focused on providing funds for disadvantaged children, library resources, textbooks, and other instructional materials to be used in elementary and secondary schools. Moreover, the act authorized several grants for higher institutions, agencies, and individuals to conduct research in education. The act has been updated several times in last five decades (National Association of School Psychologists, 2018).

\section{The Improving America's Schools Act (IASA)}

The Improving America's Schools Act (IASA) was signed by President William Jefferson Clinton in 1994 (P.L. 103-382). It reauthorized the Elementary and Secondary Education Act of 1965 (ESEA) to extend its programs for five years to increase the quality of the teaching- and learning-process for the students as well as beginning a trend of state assessments (U.S. Department of Education, 1995).

The intention of the act was to provide high-quality education for all students struggling with poverty. Thus, areas having more low-income families would receive more of funds than those with high-income families. Furthermore, states wanting to continue to receive grants were required to develop a plan of content and a plan of assessment. Additionally, states were required to develop and to conduct the assessments in at least mathematics and reading or language arts within four years. Moreover, the act established several programs to improve the quality of education.

The Eisenhower National Clearinghouse was, in addition, established in 1992 to maintain a repository of instructional materials and programs at elementary and secondary schools in science and mathematics and to coordinate databases including science and mathematics curriculum and instructional materials. The Dwight D. Eisenhower Professional Development Program of 1994 was geared to improve teaching and learning of students by providing high-quality professional development activities and funds in the core academic subjects (including science and mathematics) to educational agencies and to higher institutions (Dwight D. Eisenhower Professional Development--Federal Activities Program, CFDA No. 84.168).

Another program was the National Teacher Training Project, which was aimed at nonprofit educational institutions and designed to train selected teachers who set in-service studies for their colleagues. The act, moreover, provided funds for improving the professional development of educators. Each state was required to review and reform state requirements for teacher licensure and certification, to develop performance assessments, and to provide for the improvement of the ability of teachers in the use of technology to understand student understanding in the core subjects. Science and mathematics were given priority in improving professional development.

The Improving America's School Act of 1994 authorized several funds to support the use of technology in the teaching and learning process at the elementary and secondary schools. According to the act, the secretary of education, was to develop a national long-range plan in consultation with stakeholders like agencies and higher institutions. The states receiving the funds were required to develop a statewide educational technology plan (Education Week, 1994).

Furthermore, the IASA authorized funds to raise the quality of instruction in science and mathematics in the US elementary schools. One program was the Elementary Mathematics and Science Equipment Program (Ozfidan, Cavlazoglu, Burlbaw, \& Aydin, 2017). Equipment and materials purchases necessary for hands-on instruction were also funded through the act (Improving America's School Act of 1994).

Additionally, the Eisenhower Regional Mathematics and Science Education Consortia was established in 1995 to disseminate exemplary mathematics and science education instructional materials and to assist elementary and 
secondary school students, teachers and administrators for implementing of the teaching methods and using of the materials. The consortia comprised 10 regional centers (U.S. Department of Education, 2005).

Finally, the National Center for Educational Statistics, existing in some form since 1967, was placed under the umbrella of the United States Department of Education's Institute of Education Sciences. The Center continues to support the collection and the reporting of statistics and information to examine the condition and progress of education in United States and other nations to improve US education (NCES, n.d. c; Snyder, 1993).

\section{The No Child Left Behind Act (NCLB)}

The No Child Left Behind Act (NCLB), signed by President George W. Bush in 2002 (P.L.107-110), reauthorized the Elementary and Secondary Education Act of 1965 (ESEA) and was the main law for K-12 from 2002 to 2015. The main focus areas were student assessment, accountability systems, and the quality of teachers (Lee, n.d.).

One major goal of the act was to provide all students equally with high-quality education and to have knowledge, which reached at least at the minimum level, to meet state standards. Each state was to demonstrate that they had adopted challenging content and assessment standards; therefore, states were to have academic standards for all students at least in mathematics, reading or language arts, and science. The goal was to have all students at grade level by 2014. Additionally, each state had to have statewide annual measurable objectives that were to be set separately for the assessments of mathematics and reading or language arts (Education Policy, n.d.; Education Post, n.d.).

The act required states, in yearly assessments, to measure student academic achievement in several subjects. Under the NCLB law, states had to test students in reading and math in grades 3 through 8 and once in high school. They were required to report the results for the student population as a whole and for specific "subgroups" of students, including English-learners and students in special education, racial minorities, and children from lowincome families. States were required to bring all students to the "proficient level" on state tests by the 2013-14 school year, although each state got to decide, individually, just what "proficiency" should look like, and which tests to use.

Under the law, schools were required to assess the achievement of their goals through a "adequate yearly progress" or AYP report. If a school missed its state's annual achievement targets for two years or more, either for all students or for a particular subgroup, it was identified as not "making AYP" and was subjected a series of increasingly serious sanctions (Klein, 2015).

\section{The Every Student Succeeds Act (ESSA)}

The Every Student Succeeds Act (ESSA), signed by President Barack Obama in 2015 (P.L. 114-95). It reauthorized the Elementary and Secondary Education Act of 1965 (ESEA). The main characteristic is curtailing federal authority over the states (NASSP, n.d.).

A major goal of the act was to provide high-quality education for disadvantaged and high-need students. Each state must give an assurance that they have adopted content and achievement standards. States are to have academic standards in mathematics, reading or language arts, and science as well as in other subjects determined by the states. The adoption and implementation of the standards is not mandated, directed, coerced or exercised by the secretary of education (NASSP, n.d.).

ESSA required the states to implement a set of high-quality assessments in mathematics, reading or language arts, and science. Additionally, the state could implement assessments in any other subjects that the state deemed was an important measure of student achievement. In addition, states could exempt students in grade 8 from the mathematics assessment. The states have the right to set alternate assessment and alternate achievement standards for students with cognitive disabilities. The act required that the states must identify a statewide accountability system based on academic standards for reading or language arts and mathematics to increase student and school success (NASSP, n.d.).

ESSA has several programs to improve quality of education. One of them, the STEM Master Teacher Corps, aims to develop a statewide STEM master teacher corps. The corps seeks to increase the status of the science, technology, engineering, and mathematics teaching profession by awarding, attracting and recruiting outstanding science, technology, engineering, and mathematics teachers (American Association of Physics Teacher, n.d.).

\section{America Competes Act Reauthorization of 2010}

The America Creating Opportunities to Meaningfully Promote Excellence in Technology, Education, and Science Reauthorization Act of 2010 (P.L. 111-358), signed into law by President Barack Obama in 2011. The main characteristics of the act were the authorization of a variety of STEM education program at several federal agencies, 
which administer the programs, and improving the coordination and administration of STEM programs. The act required the OSTP to establish a committee under the NSTC to coordinate and review the programs to develop a plan for coordination to ensure that the programs do not duplicate and to report to Congress (America Competes Reauthorization Act of 2010).

\section{American Innovation and Competitiveness Act of 2017}

The American Innovation and Competitiveness Act of 2017 (P.L. 114-329), signed by the President Barack Obama in 2017. The act includes several programs at several federal agencies to promote STEM education. Additionally, it especially supported cybersecurity research. The act of 2017 aims to coordinate and administer STEM education programs. From this perspective, the act required the OMB with the consultation of OSTP to establish a body for reducing administrative burdens by focusing better on identifying and coordinating international science and technology cooperation. Moreover, an advisory panel, which evaluates CoSTEM's progress in carrying out its responsibilities and advising the coSTEM, was established. The act also aims to increase the participation of underrepresented populations in STEM education programs. Finally. The act established the responsibilities of coSTEM (American Innovation and Competitiveness Act of 2017).

\section{DISCUSSION AND CONCLUSION}

American cohorts in international assessments have relatively mediocre scores compared with their international peers, especially with respect to top performing Asian countries. In particular, the scores of American students are lower than those of Asian countries. The national assessments demonstrate that the American students' performance in science and mathematics has gained ground over years compared with earlier cohorts. However, in the globalized world, we are sure that American students should not only compete with their parents. Therefore, this study illustrated that American STEM education does not create a well-qualified population in various STEM fields.

Teacher quality has a positive impact on student performance (Allen, 2005; Darling-Hammond, 2000; Hill \& Stearns, 2015). In this study, we investigated that Science and mathematics are the least certified fields among all others and almost half of science and mathematics teachers do not hold a degree in science and mathematics. Therefore, this study supports the idea that US teaching force is a source of the insufficient performance of students on science and mathematics in the national and international assessments (Kuenzi, Matthews, \& Mangan, 2006).

In the recent years China has gained an advantage by increasing the number of recipients dramatically. China now has almost the same graduation rate as the United States in S\&E fields, while the United States has still created the largest number of baccalaureate and post baccalaureate degrees in S\&E fields over the world. Post-baccalaureate recipients are the resource of advanced research, which leads to innovations that impact the competitive edge of a nation in the globalized world. Therefore, the United States and China have the biggest capacity to have advance research. However, over $40 \%$ of temporary visa holders in the United States has doctorate degrees in S\&E fields from American higher institutions. These results showed that the US will face workforce shortages in S\&E fields. This situation influences US global economic competitiveness and national security negatively (Gonzales \& Kuenzi, 2012).

Learning STEM subjects involves extending students' meaning-making potential through language. To engage effectively with disciplinary learning, students expand their repertoires of language skills developed during the early years of schooling and learn to recognize how language is used to make meaning, discuss ideas, present knowledge, construe value, and create specialized texts across disciplines. STEM subjects are best learned with the help of teachers who can support ELs in engaging in the disciplinary practices through which both disciplinary concepts and disciplinary language are developed simultaneously. Supporting language development across STEM disciplines requires that teachers develop disciplinary concepts and practices, as well as knowledge about language and registers relevant to the discipline.

Overall, similar to previous findings (Kuenzi, Matthews, \& Mangan, 2006), this study demonstrated that American STEM education does not create well-qualified and sufficient numbers of STEM students, teachers and members of the workforce to maintain a competitive edge in a globalized world.

We concluded this study some recommendations. Students in some countries, having smaller economies and lower GDPs per capita than the US, showed higher performance than American students. China has almost same graduation rate with the US while China has lower GDP per capita. In other words, these countries were more successful with limited economic sources compared with the United States. Therefore, we argue that American STEM education investments (sources) are not used effectively. Thus, future researches should focus on the federal government's effort in STEM education to explore possible problems in existing situation and provide suggestions for better coordinating and administering STEM education investments. 
The federal government should focus on foreign graduates of S\&E fields ( $40 \%$ in doctorate level) by encouraging to stay in the United States. We suggested it because of two reasons. If current trend will continue, China will have more graduates (workforce) in S\&E fields than the United States has. Therefore, the United states will need the foreign graduates so that it can preserve its superpower in the world. On the other hand, the United States can maintain its superpower even if China has a larger STEM workforce (graduates) than the United States' workforce. We argue that, because the diversity with foreign workforce likely brings more innovative ideas and research, which has made (and will keep) America great.

\section{ACKNOWLEDGEMENT}

The researchers thank Purdue University and Prince Sultan University's Applied Linguistics Research Lab [RL$\mathrm{CH}-2019 / 6 / 9]$ for funding this research project.

\section{REFERENCES}

Allen, M. B. (2005). Eight Questions on Teacher Recruitment and Retention: What Does the Research Say? Denver, CO: Education Commission of the States (NJ3).

America Competes Reauthorization Act of 2010. Public. Law. Number. 111-358 Retrieved from http://www.gpo.gov/fdsys/pkg/PLAW-111publ358/pdf/PLAW-111publ358.pdf

American Association of Physics Teacher. (n.d.). ESSA \& Funding the STEM Master Teacher Corps: Fulfilling the nation's promise for K-12 STEM education. Retrieved from https://www.aapt.org/K12/upload/ ValueofSTEMMasterTeacherCorpstoU-S.pdf

American Innovation and Competitiveness Act of 2017. Public. Law. Number. 114-329. Retrieved from https:/ / www.congress.gov/114/plaws/publ329/PLAW-114publ329.pdf

Aydin, H., \& Cinkaya, M. (2018). Global citizenship education and diversity (GCEDS) A measure of students' attitudes related to social studies program in higher education. Journal for Multicultural Education, 12(3), 221236.

Baldi, S., Warner-Griffin, C., \& Tadler, C. (2015). Education and Certification Qualifications of Public Middle Grades Teachers of Selected Subjects: Evidence from the 2011-12 Schools and Staffing Survey. NCES 2015-815. Washington, DC: National Center for Education Statistics. Retrieved from https://nces.ed.gov/pubs2015/2015815.pdf

Becker, K., \& Park, K. (2011). Integrative approaches among Science, Technology, Engineering, and Mathematics (STEM) subjects on Student Learning: A meta-analysis. Journal of STEM Education: Innovations and Research, 12(5-6), 23-37.

Bendery, B. L. (2010). The real science gaps. Pacific Standard. Retrieved from https:/ / psmag.com/social-justice/thereal-science-gap-16191

Breiner, J. M., Harkness, S. S., Johnson, C. C., \& Koehler, C. M. (2012). What is STEM? A discussion about conceptions of STEM in education and partnerships. School Science and Mathematics, 112(1), 3-11. https:// doi.org/10.1111/j.1949-8594.2011.00109.x

Brown, R., Ernst, J., Clark, A., DeLuca, B., \& Kelly, D. (Eds.). (2017). STEM curricula. Technology and Engineering Teacher, 77(2), 26-29.

Bybee, R. W. (2010). What is STEM education? Science, 329(5995), 996. Retrieved from http:/ / science.sciencemag. org/content/329/5995/996.fullhttp:/ / science.sciencemag.org/content/329/5995/996.full

Darling-Hammond, L. (2000). Teacher Quality and Student Achievement. Education Policy Analysis Archives, 8, 1. https:// doi.org/10.14507/epaa.v8n1.2000

Duncan, A., (2010). Using Technology to Transform Schools-Remarks by Secretary Arne Duncan at the Association of American Publishers Annual Meeting. Retrieved from https:/ / www2.ed.gov/news/speeches/2010/03/03032010.html

Dwight D. Eisenhower Professional Development--Federal Activities Program, CFDA No. 84.168. Retrieved from https://www2.ed.gov/pubs/Biennial/95-96/eval/614-97.pdf

Education Policy. (n.d.). NCLB. Retrieved from https://www.newamerica.org/education-policy/policyexplainers/early-ed-prek-12/federal-education-legislation/essa/nclb/

Education Post. (n.d.). The ABC's of ESEA, ESSA and No Child Left Behind. Retrieved from http:/ / educationpost.org/the-abcs-of-esea-essa-and-no-child-left-behind/

Education Week. (1994). Summary of the Improving America's School Act. Retrieved from https://www.edweek.org/ew/articles/1994/11/09/10asacht.h14.html 
ESSA. (2018). Every Student Succeeds Act. Washington, DC: US Department of Education. Retrieved from https://www.ed.gov/essa

Fensom, A. (2017). Asia to stay world's fastest-growing region through 2030. The Diplomat. Retrieved from https:/ / thediplomat.com/2017/12/asia-to-stay-worlds-fastest-growing-region-through-2030/

Gonzalez, H. B., \& Kuenzi, J. J. (2012). Science, technology, engineering, and mathematics (STEM) education: A primer. Washington, DC: Congressional Research Service, Library of Congress.

Green, M. (2007). Science and engineering degrees: 1966-2004. (NSF 07-307). Arlington, VA: National Science Foundation.

Hill, J., \& Stearns, C. (2015). Education and certification qualifications of departmentalized public high school-level teachers of selected subjects: Evidence from the 2011-12 schools and staffing survey. NCES 2015-814. Washington, DC: National Center for Education Statistics.

Hopstock, P. J., \& Pelczar, M. P. (2011). Technical report and user's guide for the Program for International Student Assessment (PISA): 2009 data files and database with US specific variables. NCES 2011-025. Washington, DC: National Center for Education Statistics.

Hussar, W. J., \& Bailey, T. M. (2017). Projections of education statistics to 2025. NCES 2017-019. Washington, DC: National Center for Education Statistics.

Hutchinson, F. E., \& Das, S. B. (Eds.). (2016). Asia and the middle-income trap. New York, NY: Routledge. https:/ / doi.org/10.4324/9781315677606

Ilhan, F., Ozfidan, B., \& Yilmaz, S. (2019). Home Visit Effectiveness on Students' Classroom Behavior and Academic Achievement. Journal of Social Studies Education Research, 10(1), 61-80.

Improving America's School Act of 1994. Public. Law. Number. 103-382. Retrieved from https://www.congress.gov/103/bills/hr6/BILLS-103hr6enr.pdf

Kastberg, D., Chan, J. Y., \& Murray, G. (2016). Performance of U.S. 15-year-old students in science, reading, and mathematics literacy in an international context: First look at PISA. Washington, DC: US Department of Education. Retrieved from https://nces.ed.gov/pubs2017/2017048.pdf

Killewald, A., \& Xie, Y. (2013). American science education in its global and historical contexts. Bridge, 43(1), 15-23.

Klein, A. (2015). No Child Left Behind: An Overview. Retrieved from https://www.edweek.org/ew/section/ multimedia/no-child-left-behind-overview-definition-summary.html

Kuenzi, J. J., Matthews, C. M., \& Mangan, B. F. (2006). Science, technology, engineering, and mathematics (STEM) education issues and legislative options. Washington, DC: Library of Congress Congressional Research Service.

Laboy-Rush, D. (2011). Integrated STEM education through project-based learning. Portland, OR: Learning. Com. Retrieved from http:/ / www.rondout.k12.ny.us/common/pages/DisplayFile.aspx

Lee, A. M. I. (n.d.). No Child Left Behind (NCLB): What you need to know. Retrieved from https://www. understood.org/en/school-learning/your-childs-rights/basics-about-childs-rights/no-child-left-behindnclb-what-you-need-to-know

Lockheed, M. (2015). Why do countries participate in international large-scale assessments? The Case of PISA. World Bank Policy Research Working Paper No. 7447. Washington, DC: World Bank. Available at SSRN https: / / ssrn.com/abstract $=2676416$

Machi, E. (2009). Improving US competitiveness with K-12 STEM education and training. Heritage special report. SR-57. A report on the STEM education and National Security Conference, October 21-23, 2008. Washington, DC: Heritage Foundation. Retrieved from https:/ / files.eric.ed.gov/fulltext/ED505842.pdf

Madden, L., Beyers, J., \& O’Brien, S. (2016). The importance of STEM education in the elementary grades: Learning from pre-service and novice teachers' perspectives. Electronic Journal of Science Education, 20(5), 1-18.

Martin, M., Mullis, I., Foy, P., \& Hooper, M. (2016). TIMSS 2015 international results in science. Boston, MA: TIMSS and PIRLS International Study Centre, Lynch School of Education, Boston College.

McLaughlin, M. (1975). Evaluation and reform: The Elementary and Secondary Education Act of 1965, Title I. Cambridge, MA: Ballinger Publishing Company.

Mills, A. (2017). What is STEM education? Retrieved from http://www.mtu.edu/news/stories/2017/september/ what-stem-education.html

Morrison, W. M. (2018). China's Economic Rise: History, Trends, Challenges, and Implications for the United States. Washington, DC: Congressional Research Service, Library of Congress. 
Mullis, I. V. S., \& Martin, M. O. (Eds.). (2017). TIMSS 2019 assessment frameworks. Boston, MA: TIMSS \& PIRLS International Study Center, Boston College. Retrieved from http:/ / timssandpirls.bc.edu/timss2019/frameworks/

Mullis, I., Martin, M., Foy, P., \& Hooper, M. (2016). TIMSS 2015 international results in mathematics. Boston, MA: TIMSS \& PIRLS International Study Center, Boston College.

NASSP. (n.d.). Every Student Succeed Act (ESSA) Overview. Retrieved from https://www.nassp.org/policyadvocacy-center/resources/essa-toolkit/essa-fact-sheets/every-student-succeeds-act-essa-overview /

National Association of School Psychologists. (2018). Elementary and Secondary Education Act (ESEA). Retrieved from https:/ / www.nasponline.org/research-and-policy/current-law-and-policy-priorities/current-law/ elementary-and-secondary-education-act-(esea)

NCES. (2013). The nation's report card: Trends in academic progress 2012 (NCES 2013 456). Washington, DC: Institute of Education Sciences, U.S. Department of Education.

NCES. (n.d. a). NAEP overview. Retrieved from https:/ / nces.ed.gov/nationsreportcard/about/

NCES. (n.d. b). TIMSS overview. Retrieved from https://nces.ed.gov/timss/

NCES. (n.d. c). NTPS overview. Retrieved https://nces.ed.gov/surveys/ntps/overview.asp

NCES. (n.d. d). National Center for Education Statistics. Retrieved from https:/ / nces.ed.gov/about/

NRC. (2011). Successful K-12 STEM education: Identifying effective approaches in science, technology, engineering, and mathematics. Committee on Highly Successful Science Programs for K-12 Science Education. Board on Science Education and Board on Testing and Assessment, Division of Behavioral and Social Sciences and Education. Washington, DC: The National Academies Press.

NSB. (2018a). Science and engineering indicators 2018. Alexandria, VA: National Science Foundation. Retrieved from https:/ / www.nsf.gov/statistics/indicators/

NSB. (2018b). Science and engineering indicators 2018 digest. Alexandria, VA: National Science Foundation. Retrieved from https:/ / www.nsf.gov/statistics/digest/

NSTC. (2013). Federal science, technology, engineering, and mathematics (STEM) edu. 5-year strategic plan. Retrieved from https:/ / obamawhitehouse.archives.gov/sites/default/files/microsites/ostp/stem_stratplan_2013.pdf

Ntemngwa, C., \& Oliver, S. (2018). The implementation of integrated science technology, engineering and mathematics (STEM) instruction using robotics in the middle school science classroom. International Journal of Education in Mathematics, Science and Technology, 6(1), 12-40. https:/ / doi.org/10.18404/ijemst.380617

OECD. (2017). PISA 2015 technical report. Retrieved from http:/ / www.oecd.org/pisa/data/2015-technical-report/

OECD. (n.d. a). About the OECD. Retrieved from http:/ / www.oecd.org/about/

Ozfidan, B., \& Burlbaw, L. M. (2016). Perceptions of bilingual education model in Spain: How to implement a bilingual education model in Turkey. Journal of Ethnic and Cultural Studies, 3(1), 49-58.

Ozfidan, B., \& de Miranda, M. A. (2017). K12 Teacher Credentialing Containing Engineering Content in the USA. Eurasia Journal of Mathematics, Science and Technology Education, 14(1), 3-13. https:// doi.org/10.12973/ejmste/76888

Ozfidan, B., \& Toprak, M. (2019). Cultural Awareness on A Bilingual Education: A Mixed Method Study. Multicultural Learning and Teaching.

Ozfidan, B., Cavlazoglu, B., Burlbaw, L., \& Aydin, H. (2017). Reformed Teaching and Learning in Science Education: A Comparative Study of Turkish and US Teachers. Journal of Education and Learning. 6 (3), 23-30. https://doi.org/10.5539/jel.v6n3p23

Sanders, M. E. (2009). STEM, STEM education, STEMmania. The Technology Teacher, 68(4), 20-26.

Snyder, T. D., de Brey, C., \& Dillow, S. A. (2018). Digest of education statistics 2016 (NCES 2017-094). Retrieved from https:/ / nces.ed.gov/pubs2017/2017094.pdf

Synder, T. (1993). 120 Years of American education: A statistical portrait. Retrieved from https:/ / nces.ed.gov/pubs93/93442.pdf

Tanenbaum, C. (2016). STEM 2026: A vision for innovation in STEM education. Retrieved from https://innovation.ed.gov/what-we-do/stem/

Toppo, G. (2008). U.S. students' math, science scores deliver mixed results. Retrieved from https:/ / usatoday30.usatoday.com/tech/science/mathscience/2008-12-09-math-sci-scores_n.htm 
U.S. Department of Education. (1995). The improving America's Schools Act of 1994. Retrieved from https:// www2.ed.gov/offices/OESE/archives/legislation/ESEA/brochure/iasa-bro.html

U.S. Department of Education. (2005). Eisenhower Regional Mathematics and Science Education Consortia. Retrieved from https:/ / www2.ed.gov/programs/encconsortia/index.html?exp=0 


\section{APPENDIX A}

TIMSS Average Mathematics Scores of grades 8 and 4, by Education System: 1995-2015

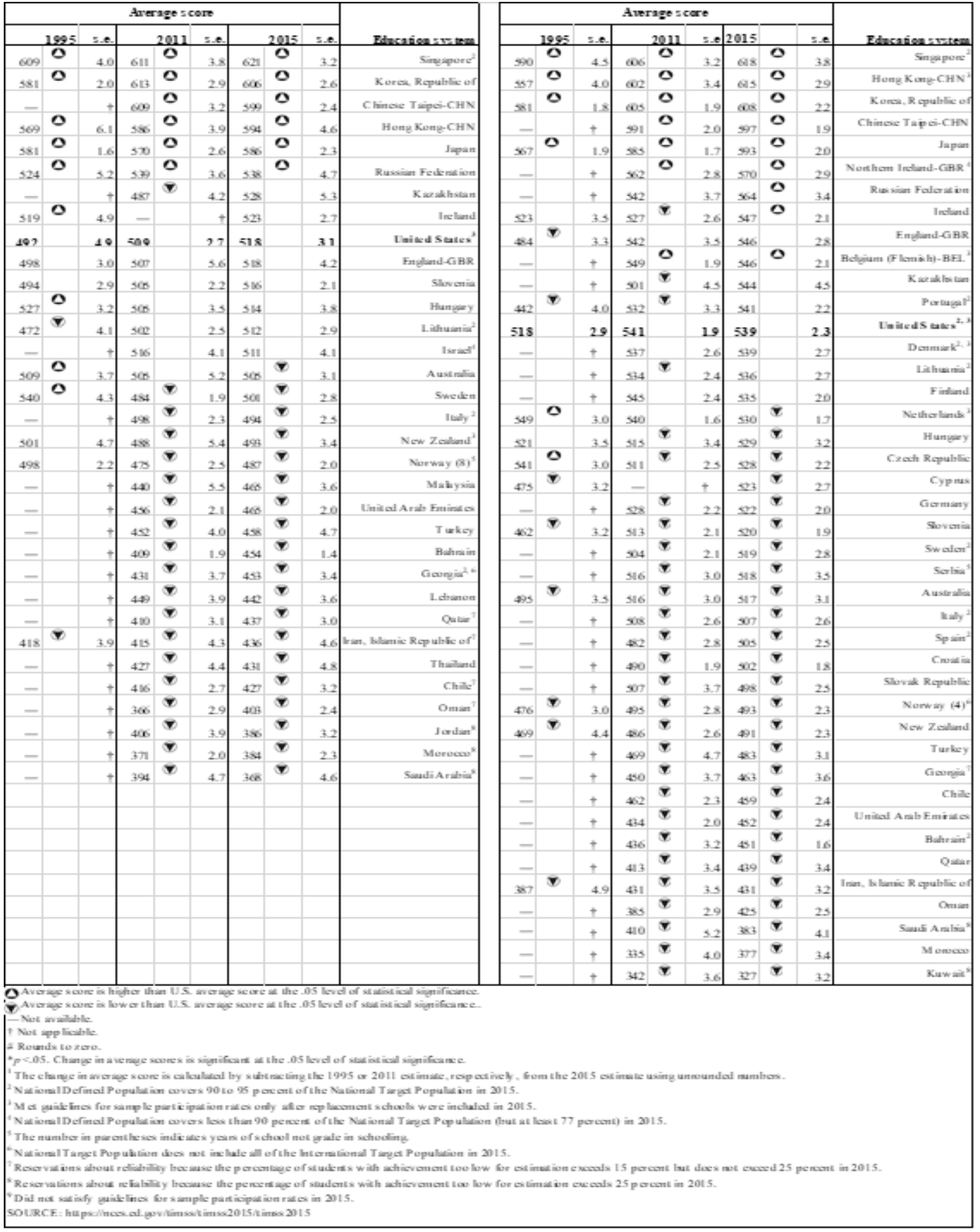




\section{APPENDIX B}

TIMSS Average Science Scores of Grades 8 and 4 by Educational System: 1995-2015

\begin{tabular}{|c|c|c|c|c|c|c|c|c|c|c|c|c|c|c|c|c|c|c|c|}
\hline \multicolumn{9}{|c|}{ Arverage s corte } & \multirow[b]{2}{*}{ Fdncaion avitem } & \multicolumn{9}{|c|}{ Average s care } & \multirow[b]{2}{*}{ Fdacafien avater } \\
\hline \multicolumn{2}{|c|}{1995} & \multirow[t]{2}{*}{ s.e. } & \multicolumn{3}{|c|}{$2011=0$} & \multicolumn{2}{|c|}{2015} & \multirow{2}{*}{$=-0$} & & \multicolumn{2}{|r|}{1995} & \multirow{2}{*}{$=0}$. & \multicolumn{2}{|r|}{2011} & $=-0$ & 2015 & & $=-e$ & \\
\hline 609 & 0 & & 611 & 0 & 3.8 & 621 & 0 & & Sinespore & 950 & 0 & & 106 & 0 & 32 & A8 8 & 0 & 38 & Singepore \\
\hline$\$ 81$ & 0 & 20 & 613 & 0 & 29 & $\infty \infty$ & 0 & 26 & Kersa, Repultic of & ss & 0 & 40 & $\omega 2$ & 0 & 3.4 & as & 0 & 29 & Heng King-CHN ${ }^{2}$ \\
\hline- & & + & $\infty \theta$ & 0 & 3.2 & 59 & 0 & 24 & Clinsed Tapsi-CHN & 581 & 0 & 1.8 & $\cos$ & 0 & 1.9 & $\cos$ & 0 & 222 & Kensos, R quillic of \\
\hline 509 & 0 & 6.1 & 58 & 0 & 3.9 & 594 & 0 & 4.6 & Hong Kone-CHN & - & & + & 991 & 0 & 20 & $\$ 97$ & 0 & 19 & Chincese Tapoi-CHN \\
\hline$\$ \$ 1$ & 0 & 16 & 50 & 0 & 26 & 58 & 0 & 23 & Japan & 267 & 0 & 1.9 & sos & 0 & 1.7 & 993 & 0 & 20 & Japient \\
\hline$\$ 24$ & 0 & $\leq 2$ & 597 & 0 & 3.6 & 538 & 0 & 4.7 & Ruscian Fedrativen & - & & + & $s \times 2$ & 0 & 28 & sno & 0 & 29 & Nerthem Ireliand-GasR \\
\hline- & & + & 485 & $\nabla$ & 42 & $5 \mathbf{x}$ & & 53 & 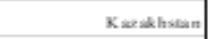 & - & & + & $\$ 42$ & & 3.7 & $\$ 64$ & 0 & 34 & Rusian Foleritivn \\
\hline$\$ 19$ & 0 & 4.9 & - & & + & 523 & & 27 & Irelland & $\leq 23$ & & 3.5 & 57 & $\nabla$ & 26 & 347 & 0 & 21 & Ireliand \\
\hline 407 & & 40 & $=00$ & & 27 & 518 & & 31 & Laided States $x^{3}$ & $4: 4$ & $\nabla$ & 3.3 & $\$ 42$ & & 3.5 & 546 & & 28 & Fneliand-GAR \\
\hline 498 & & 30 & $s 00$ & & 56 & 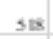 & & 4.2 & FneliandG $\mathrm{BR}$ & - & & + & $\$ 49$ & 0 & 1.9 & $\$ 46$ & 0 & 21 & 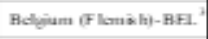 \\
\hline 494 & & 29 & 500 & & 22 & 516 & & 2.1 & Sheveria & - & & + & 301 & $\nabla$ & 4.5 & $\$ 44$ & & 45 & 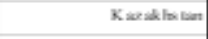 \\
\hline 527 & 0 & 3.2 & 500 & & 3.5 & 514 & & 3.8 & Hunyery & 442 & $\nabla$ & 40 & $\$ 32$ & $\nabla$ & 3.3 & 341 & & 222 & Porlagentit \\
\hline 472 & $\nabla$ & 4.1 & $s e$ & & 25 & 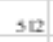 & & 29 & 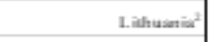 & 518 & & 29 & 541 & & 19 & 539 & & 2.3 & De inedS tases ${ }^{2,3}$ \\
\hline- & & + & 516 & & 4.1 & sil & & 4.1 & Isract' & - & & + & $\$ 37$ & & 26 & $\$ 99$ & & 27 & Dermaze $k^{2}, 3$ \\
\hline 509 & 0 & 3.7 & 500 & & $5: 2$ & 500 & $\nabla$ & 3.1 & Austrists & - & & + & $\$ 4$ & $\nabla$ & 24 & 536 & & 27 & Lithusini \\
\hline 540 & 0 & 4.3 & 484 & $\nabla$ & 1.9 & 500 & $\nabla$ & 28 & Sweits & - & & + & 545 & & 24 & $\leq 35$ & & 20 & Findland \\
\hline- & & + & 498 & $\nabla$ & 23 & 494 & $\nabla$ & 2.5 & Indy $y^{2}$ & $\$ 49$ & 0 & 300 & $\$ 40$ & & 1.6 & $\leq 0$ & $\boldsymbol{\tau}$ & 13 & Nedhorlunib: \\
\hline sot & & 4.7 & 488 & $\nabla$ & 5.4 & 498 & $\nabla$ & 3.4 & New Zelland ${ }^{3}$ & $\leq 1$ & & 3.5 & sis & $\nabla$ & 3.4 & $\leq 9$ & $\nabla$ & 32 & Hungery \\
\hline 498 & & 22 & $4 \pi$ & $\nabla$ & $2 s$ & 480 & $\nabla$ & 20 & Nurway $(8)^{3}$ & $\$ 41$ & 0 & 30 & sit & $\boldsymbol{v}$ & 25 & 58 & $\mathbf{v}$ & 22 & Ceach Repultilic \\
\hline- & & + & 40 & $\nabla$ & s.s. & 400 & $\nabla$ & 36 & Mahyom & 4rs & $\nabla$ & 3.2 & - & & + & $\leq 2$ & $\nabla$ & 20 & Cypux \\
\hline- & & + & 486 & $\nabla$ & 2.1 & 400 & $\nabla$ & 20 & Unital Arub Frimito o & - & & + & 58 & $\nabla$ & 22 & $\$ 2$ & $\nabla$ & 20 & Germiany \\
\hline- & & + & 45 & $\nabla$ & 40 & 488 & $\nabla$ & 4.7. & Tukey & $4 \times 2$ & $\nabla$ & 3.2 & s.13 & $\nabla$ & 2.1 & $\leq 0$ & $\boldsymbol{\nabla}$ & 19 & Stovenis \\
\hline- & & + & 40 & $\nabla$ & 1.9 & 454 & $\nabla$ & 1.4 & Holhas in & - & & + & 204 & $\nabla$ & 2.1 & ș9 & $\nabla$ & 28 & Swalon' \\
\hline- & & + & 430 & $\nabla$ & 3.7 & 453 & $\nabla$ & 3.4 & Gaverist & - & & + & 546 & $\nabla$ & 3.0 & sis & $\nabla$ & 35 & Sertisis \\
\hline- & & + & 49 & $\nabla$ & 3.9 & 40 & $\nabla$ & 3.6 & L.edranen & 495 & $\nabla$ & 35 & s16 & $\nabla$ & 30 & sis 7 & $\nabla$ & 3. & Austerils \\
\hline- & & + & 400 & $\nabla$ & 3.1 & 437 & $\nabla$ & 30 & $\alpha_{a}={ }^{7}$ & - & & + & $s 08$ & $\nabla$ & 26 & 207 & $\nabla$ & 26 & kaly \\
\hline 418 & $\nabla$ & 3.9 & 415 & $\nabla$ & 43 & 436 & $\nabla$ & 46 & 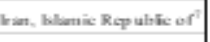 & - & & + & $4 \times 2$ & $\nabla$ & 28 & sos & $\nabla$ & 2.5 & $S_{p} \sin ^{2}$ \\
\hline- & & + & 427 & $\nabla$ & 4.4 & 430 & $\nabla$ & 48 & Thullind & - & & + & 400 & $\nabla$ & 1.9 & $s 02$ & $\nabla$ & 18 & Covidis \\
\hline- & & + & 416 & $\nabla$ & 27 & 420 & $\nabla$ & 32 & Chint & - & & + & 307 & $\nabla$ & 3.7 & 498 & $\nabla$ & 25 & Sloved Repultic: \\
\hline- & & + & 306 & $\nabla$ & 29 & 403 & $\nabla$ & 24 & Omin? & 476 & $\nabla$ & 30 & 495 & $\nabla$ & 28 & 493 & $\nabla$ & 2.3 & Noeway $(4)^{t}$ \\
\hline- & & + & 406 & $\nabla$ & 3.9 & 386 & $\nabla$ & 32 & Jardian $x$ & 400 & $\nabla$ & 4.4 & 406 & $\nabla$ & 26 & 491 & $\nabla$ & 2.3 & New Zevland \\
\hline- & & + & $3 \pi$ & $\nabla$ & 20 & 334 & $\nabla$ & 23 & Morveex & - & & + & 409 & $\nabla$ & 4.7 & $4 \times 3$ & $\boldsymbol{v}$ & 3 & Turkey \\
\hline- & & + & 394 & $\nabla$ & 4.7. & 368 & $\nabla$ & 4.6 & 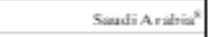 & - & & + & $4 \div 0$ & $\nabla$ & 3.7 & 463 & $\nabla$ & 36 & Gwong- \\
\hline & & & & & & & & & & - & & + & 462 & $\boldsymbol{\nabla}$ & 23 & $4 \% 9$ & $\boldsymbol{\nabla}$ & 24 & Chille \\
\hline & & & & & & & & & & - & & + & 434 & $\nabla$ & 20 & $4 \leqslant 2$ & $\nabla$ & 24 & Unital Arabl Emizato \\
\hline & & & & & & & & & & - & & + & 436 & $\nabla$ & 32 & 451 & $\boldsymbol{T}$ & 16 & Fulhriann \\
\hline & & & & & & & & & & - & & + & 413 & $\nabla$ & 3.4 & 439 & $\boldsymbol{v}$ & 34 & Q Quar \\
\hline & & & & & & & & & & $3 \times 7$ & $\nabla$ & 4.9 & 431 & $\nabla$ & 3.5 & 431 & $\nabla$ & 32 & Inen, b lianic $\mathbb{R}$ cquihlic ef \\
\hline & & & & & & & & & & - & & + & $3 \times 5$ & $\nabla$ & 29 & es & $\nabla$ & 25 & Omiat \\
\hline & & & & & & & & & & - & & + & 400 & $\boldsymbol{\nabla}$ & $5: 2$ & $3 \times 3$ & $\nabla$ & 4. & Sounci Ansiss" \\
\hline & & & & & & & & & & - & & + & 335 & $\nabla$ & 4.0 & $m$ & $\boldsymbol{v}$ & 34 & M ewerov \\
\hline & & & & & & & & & & - & & + & 342 & $\boldsymbol{\tau}$ & 3.6 & 327 & $\boldsymbol{T}$ & 32 & Kuwins \\
\hline 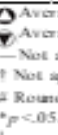 & 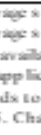 & & & & & & & & 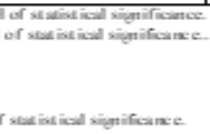 & & & & & & & & & & \\
\hline $\begin{array}{l}\text { 'The } \\
\text { 'Nutive }\end{array}$ & $\begin{array}{l}\text { lame } \\
\text { maly }\end{array}$ & & sp & $\ln$ ، & & & & & & & & & & & & & & & \\
\hline 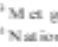 & pis & & an: & $n$ & & & & & Aival T Ta & & & & & & & & & & \\
\hline 'Then: & $u m$ & & nthes & in & $x y=$ & $x$ of $x$ & the & & moving & & & & & & & & & & \\
\hline Nasive & malt & & & vن a & a in & e & & & 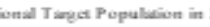 & & & & & & & & & & \\
\hline & & & & & & & & & & & & & & & & & & & \\
\hline - & & & & & & & & & & & & & & & & & & & \\
\hline & & & & & & & & & & & & & & & & & & & \\
\hline
\end{tabular}




\section{APPENDIX C}

Average Scores and Changes in Average Scores of U.S. Students on PISA Science, Mathematics, and Reading; 2000, 2003, 2006, 2009, 2012, and 2015

\begin{tabular}{|c|c|c|c|c|c|c|c|c|c|c|}
\hline \multirow[b]{2}{*}{ Subject } & \multicolumn{2}{|c|}{2000} & & 2006 & 2009 & 2012 & 2015 & \\
\hline & $\begin{array}{r}\text { Average } \\
\text { score }\end{array}$ & s.e. & $\begin{array}{l}\begin{array}{l}\text { Average } \\
\text { score s.e. }\end{array} \\
\end{array}$ & $\begin{array}{l}\text { Average } \\
\text { score s.e. }\end{array}$ & $\begin{array}{l}\begin{array}{l}\text { Average } \\
\text { score s.e. }\end{array} \\
\end{array}$ & $\begin{array}{l}\begin{array}{l}\text { Average } \\
\text { score s.e. }\end{array} \\
\end{array}$ & $\begin{array}{l}\text { Average } \\
\text { score s.e. }\end{array}$ & $\begin{array}{r}2015-2015-2 \\
2000 \quad 2003 \\
\end{array}$ & $\begin{array}{r}2015- \\
2006 \\
\end{array}$ & $\begin{array}{r}2015-2015- \\
2009 \quad 2012 \\
\end{array}$ \\
\hline Science literacy & $t$ & $\dagger$ & & 4894.2 & 5023.6 & $4 9 7 \longdiv { 3 . 8 }$ & 4963.2 & $\dagger$ & 0 & 00 \\
\hline Mathematics literacy & $t$ & $t$ & 4832.9 & 4744.0 & 4873.6 & 4813.6 & 4703.2 & 8 & 0 & \\
\hline
\end{tabular}

A Average score in 2015 is not measurably different than in comparison year at the .05 level of statistical significance.

- Average score in 2015 is lower than in comparison year at the. 05 level of statistical significance.

- Not avallable. PISA 2006 reading literacy results are not reported for the United States because of an error in printing the test booklets making comparisons not possible.

† Not applicable. Although science was assessed in 2000 and 2003, because the science framework was revised for 2006, it is possible to look at changes in science only from 2006 lorward. Similarly, athough mathematics was assessed in 2000, because the mathematics framework was revised for PISA 2003 , it is possible to look at changes in mathematics only from 2003 forward.

NOTE All average scores reported as higher or lower than the comparison year are different at the 05 level of statistical significance. Standard error is noted by s.e. This table corresponds to table 4 in Porformance of U.S. 15-Year-Old Students in Science, Mathemabcs, and Reading Literacy in an international Context (NCES 2017-048

SOURCE Organization for Economic Cooperation and Development (OECD). Program for International Student Assessment (PISA). 2000, 2003. 2006, 2009, 2012, and 2015 . 


\section{APPENDIX D}

PISA Average Scores in Mathematics, by Education System: 2015

\begin{tabular}{|c|c|c|c|c|c|}
\hline E ducation system & Avernge score & s.e. & E ducation system & Average score & s.e. \\
\hline OECD average & 4900 & 0.4 & Israel & 470 & 3.6 \\
\hline Singapore & 5640 & 1.5 & United States & 470 & 3.2 \\
\hline Hong Kong (China) & 5480 & 3.0 & Croatia & 464 & 2.8 \\
\hline Macau (China) & 5440 & 1.1 & Buenos Aires (Argentina) & 456 & 0.9 \\
\hline Chinese Taipei & 5420 & 3.0 & Greece & $454 \nabla$ & 3.8 \\
\hline Japan & 5320 & 3.0 & Romania & $444 \nabla$ & 3.8 \\
\hline B-S-J-G (China) & 5310 & 4.9 & Bulgaria & $441 \nabla$ & 4.0 \\
\hline Korea, Republic of & 5240 & 3.7 & Cyprus & $437 \nabla$ & 1.7 \\
\hline Switzerland & 5210 & 2.0 & United Arab Emirates & $427 \nabla$ & 2.4 \\
\hline Estonia & 5200 & 2.0 & Chile & $423 \nabla$ & 2.5 \\
\hline Canada & 5160 & 2.3 & Turkey & $420 \nabla$ & 4.1 \\
\hline Netherlands & 5120 & 2.2 & Moldova, Republic of & $420 \nabla$ & 2.5 \\
\hline Denmatk & 5110 & 2.2 & Uruguay & $418 \nabla$ & 2.5 \\
\hline Finland & 5110 & 2.3 & Montenegro, Republic of & $418 \nabla$ & 1.5 \\
\hline Slovenia & 5100 & 1.3 & Trinidad and Tobago & $417 \nabla$ & 1.4 \\
\hline Belgium & 5070 & 2.4 & Thailand & $415 \nabla$ & 3.0 \\
\hline Germany & 5060 & 2.9 & Albania & $413 \nabla$ & 3.4 \\
\hline Poland & 5040 & 2.4 & Mexico & $408 \nabla$ & 2.2 \\
\hline Ireland & 5040 & 2.1 & Georgia & $404 \nabla$ & 2.8 \\
\hline Norway & 5020 & 2.2 & Qatar & $402 \nabla$ & 1.3 \\
\hline Austria & 4970 & 2.9 & Costa Rica & $400 \nabla$ & 2.5 \\
\hline New Zealand & 4950 & 2.3 & Lebanon & $396 \nabla$ & 3.7 \\
\hline Vietnam & 4950 & 4.5 & Colombia & $390 \nabla$ & 2.3 \\
\hline Russian Federation & 4940 & 3.1 & Peru & $387 \nabla$ & 2.7 \\
\hline Sw eden & 4940 & 3.2 & Indonesia & $386 \nabla$ & 3.1 \\
\hline Australia & 4940 & 1.6 & Jordan & $380 \nabla$ & 2.7 \\
\hline France & ${ }_{493} \boldsymbol{O}$ & 2.1 & Brazil & $377 \boldsymbol{\nabla}$ & 2.9 \\
\hline United King dom & 4920 & 2.5 & Macedonia, Republic of & $371 \nabla$ & 1.3 \\
\hline Czech Republic & 4920 & 2.4 & Tunisia & $367 \nabla$ & 3.0 \\
\hline Portugal & 4920 & 2.5 & Kosovo & $362 \nabla$ & 1.6 \\
\hline Italy & 4900 & 2.8 & Algeria & $360 \nabla$ & 3.0 \\
\hline Iceland & 4880 & 2.0 & Dominican Republic & 328 & 2.7 \\
\hline Spain & 4860 & 2.2 & & & \\
\hline Luxembourg & 4860 & 1.3 & & & \\
\hline Latvia & 4820 & 1.9 & & & \\
\hline Malta & 4790 & 1.7 & U.S. states and territories & & \\
\hline Lithuania & 4780 & 2.3 & Massachusetts & $500 \overline{0}$ & 5.5 \\
\hline Hungary & 477 & 2.5 & North Carolina & 471 & 4.4 \\
\hline Slovak Republic & 475 & 2.7 & Puerto Rico & $378 \nabla$ & 5.0 \\
\hline
\end{tabular}

0 A verage score is higher than U.S. average score at the .05 level of statis ticals ignificance.

(1) A verage score is lower than U.S. average score at the .05 level of statis tical significance.

NOTE: Edvcation systems are ordered by 2015 average score. The $O E C D$ average is the average of the nationalaverages of the OBCD member countries, with each country weighted equatly. Scores are reported on a scale from 0 to 1,000 . Standard error is noted by s.e. Italics indicate non-OECD countries and edvcation sys tems. B-S-J-G (China) refers to the four PISA participating China provinces: Beijing, Shang hai, Jiangsu, and Guan gdong. Results for Mass achusetts and North Carolina are for public school students only. Atthough Argen tina, Malaysia, and Kazakhstan participated in PISA 2015, technical problems with their s amples prevent results frombeing dis cussed in this report. This table corresponds to table 3 in Performance of U.S. 15-YearOld Students in Science, Mathematics, and Reading Lite raxy in an International Context (NCES 2017-048).

SOURCE: https :/nces .ad gov/surveys/pis a p isa 2015/pis a201/Shighlights_5a_l asp 


\section{APPENDIX E}

PISA Average Scores in Science, by Education System: 2015

\begin{tabular}{|c|c|c|c|c|c|}
\hline E ducation & Average score & s.e. & Education system & Avernge score & s.e. \\
\hline OECD average & 493 & $\overline{0.4}$ & Iceland & $473 \nabla$ & 1.7 \\
\hline Singapore & 5560 & 1.2 & Irrael & $467 \nabla$ & 3.4 \\
\hline Japan & 5380 & 3.0 & Malta & $465 \nabla$ & 1.6 \\
\hline Estonia & 5340 & 2.1 & Slovak Republic & $461 \nabla$ & 2.6 \\
\hline Chinese Taipei & 5320 & 2.7 & Greece & $455 \nabla$ & 3.9 \\
\hline Finland & 5310 & 2.4 & Chile & $447 \nabla$ & 2.4 \\
\hline Macau (China) & 5290 & 1.1 & Bulgaria & $446 \nabla$ & 4.4 \\
\hline Canada & 5280 & 2.1 & United_Arab Emirates & $437 \nabla$ & 2.4 \\
\hline Vietnam & 5250 & 3.9 & Uruguay & $435 \nabla$ & 2.2 \\
\hline Hong Kong (China) & 5230 & 2.5 & Romania & $435 \nabla$ & 3.2 \\
\hline$B-S J-G$ (China) & 5180 & 4.6 & Cyprus & $433 \nabla$ & 1.4 \\
\hline Korea, Republic of & 5160 & 3.1 & Moldova, Republic of & $428 \nabla$ & 2.0 \\
\hline New Zealand & 5130 & 2.4 & Albania & $427 \nabla$ & 3.3 \\
\hline Slovenia & 5130 & 1.3 & Turkey & $425 \nabla$ & 3.9 \\
\hline Australia & 5100 & 1.5 & Trinidad and Tobago & $425 \nabla$ & 1.4 \\
\hline United Kingdom & 5090 & 2.6 & Thailand & $421 \nabla$ & 2.8 \\
\hline Germany & 5090 & 2.7 & Costa Rica & $420 \nabla$ & 2.1 \\
\hline Netherlands & 5090 & 2.3 & Qatar & $418 \nabla$ & 1.0 \\
\hline Sw itzerland & 5060 & 2.9 & Colombia & $416 \nabla$ & 2.4 \\
\hline Ireland & 503 & 2.4 & Mexico & $416 \nabla$ & 2.1 \\
\hline Belgium & 502 & 2.3 & Montenegro, Republic of & $411 \nabla$ & 1.0 \\
\hline Denmark & 502 & 2.4 & Georgia & $411 \nabla$ & 2.4 \\
\hline Poland & 501 & 2.5 & Jordan & $409 \nabla$ & 2.7 \\
\hline Portugal & 501 & 2.4 & Indonesia & $403 \nabla$ & 2.6 \\
\hline Norway & 498 & 2.3 & Brazil & $401 \nabla$ & 2.3 \\
\hline United States & 496 & 3.2 & Peru & $397 \nabla$ & 2.4 \\
\hline Austria & 495 & 2.4 & Lebanon & $386 \nabla$ & 3.4 \\
\hline France & 495 & 2.1 & Tunisia & $386 \nabla$ & 2.1 \\
\hline Sw eden & 493 & 3.6 & Macedonia, Republic of & $384 \nabla$ & 1.2 \\
\hline Czech Republic & 493 & 2.3 & Kosove & $378 \nabla$ & 1.7 \\
\hline Spain & 493 & 2.1 & Algeria & $376 \nabla$ & 2.6 \\
\hline Latvia & 490 & 1.6 & Dominic an Republic & $332 \nabla$ & 2.6 \\
\hline Russian Federation & $487^{\nabla}$ & 2.9 & & & \\
\hline Luxembourg & $483^{\nabla}$ & 1.1 & & & \\
\hline Italy & $481^{\nabla}$ & 2.5 & & & \\
\hline Hungary & $477^{\nabla}$ & 2.4 & \multicolumn{3}{|l|}{ U.S. states and territories } \\
\hline Lithuania & $475^{\nabla}$ & 2.7 & Massachusetts & 5290 & 0.0 \\
\hline Croatia & $475^{\nabla}$ & 2.5 & North Carolina & 502 & 4.9 \\
\hline Buenos Aires (Argentina) & $475 \nabla$ & 0.3 & Puerto Rico & $403 \nabla$ & 0.1 \\
\hline
\end{tabular}

Buenos Aires (Argentina)

Puerto Rico

A Average score is higher than U.S. average score at the .05 level of statistical significance.

V Average score is lower than U.S. average score at the .05 level of statistical significance.

NOTE: Edvcation systems are ordered by 2015 average $s c 0 r e$. The OBCD average is the avera ge of the national averages of the OBCD member countries, with each country we ighted equatly. Scores are reported on a scale from 0 to 1,000 . All average scores reported as higher or lower than the U.S. avera ge score are different at the .05 level of statis ticals ignific ance. Italics indicate non- $O E C D$ countries and edvcation sys tems. B-S-J-G(China) refers to the four PISA partic ipating China provinces: Beijing, Shanghai, Jiang su, and Guangd ong. Results for Massachusetts and North Carolina are for public school students only. A though Argentina, Malaysia, and Kazalhstan participated in PISA 2015, techn icalproblems with the ir samples prevent results frombeing discussed in this report. This table corresponds to table 1 in Performance ofU.S. 15-Year-Old Students in Science, Mathematics, and Reading Literacy in an Intemational Context (NCBS 2017-048).

SOURCE: https //nces ad gov/surveys/pis a pisa 2015/pis a201 Shighlights_3.asp 


\section{APPENDIX F}

\section{Number of Departmentalized Public Middle Grades Teachers who Reported a Particular Main Assignment and the Percentage of Teachers who Taught Various Percentages of Classes within that Main Assignment, by Subject of Main Assignment: 2011-12}

\begin{tabular}{|c|c|c|c|c|c|c|c|c|}
\hline \multirow[b]{2}{*}{ Selected main assignment } & \multirow[b]{2}{*}{$\begin{array}{r}\text { Number } \\
\text { of teachers }\end{array}$} & \multicolumn{3}{|c|}{$\begin{array}{c}\text { Percent with a major in } \\
\text { main assignment }\end{array}$} & \multicolumn{3}{|c|}{$\begin{array}{c}\text { Percent with no major in } \\
\text { main assignment }\end{array}$} & \multirow[b]{2}{*}{$\begin{array}{r}\begin{array}{r}\text { Total } \\
\text { certified }\end{array} \\
\end{array}$} \\
\hline & & Total & Certified & $\begin{array}{r}\text { Not } \\
\text { certified } \\
\end{array}$ & Total & Certified & $\begin{array}{r}\text { Not } \\
\text { certified } \\
\end{array}$ & \\
\hline English & 139,100 & 46.1 & 36.3 & 9.8 & 53.9 & 20.4 & 33.4 & 56.7 \\
\hline Mathematics & 116,100 & 28.1 & 21.9 & 6.3 & 71.9 & 31.0 & 40.9 & 52.9 \\
\hline Science & 86,400 & 44.9 & 33.1 & 11.7 & 55.1 & 23.7 & 31.5 & 56.8 \\
\hline Biology/life sciences & 12,100 & 44.7 & 22.5 & 22.2 & 55.3 & 10.7 & 44.6 & 33.2 \\
\hline Physical science & 25,700 & 16.6 & 7.3 & 9.4 & 83.4 & 13.9 & 69.5 & 21.2 \\
\hline Earth sciences & 9,100 & 18.0 & $6.2 !$ & $11.8 !$ & 82.0 & 14.0 & 68.0 & 20.2 \\
\hline Social science & 79,200 & 51.6 & 40.4 & 11.3 & 48.4 & 22.1 & 26.2 & 62.5 \\
\hline Geography & 5,200 & $\ddagger$ & $\#$ & $\ddagger$ & 98.7 & 11.5 & 87.2 & 11.5 \\
\hline Government/civics & 2,200 & $\ddagger$ & $\ddagger$ & $\ddagger$ & 95.8 & $\ddagger$ & 78.8 & $\ddagger$ \\
\hline History & 29,500 & 33.0 & 17.3 & 15.8 & 67.0 & 15.1 & 51.8 & 32.4 \\
\hline French & 3,600 & 84.8 & 76.2 & $\ddagger$ & $15.2 !$ & $\ddagger$ & $\ddagger$ & 88.6 \\
\hline German & 500 & 72.1 & $55.3 !$ & $\ddagger$ & $\ddagger$ & $\ddagger$ & $\#$ & 83.2 \\
\hline Spanish & 10,900 & 65.7 & 56.1 & $9.6 !$ & 34.3 & 26.5 & $7.8 !$ & 82.6 \\
\hline Art/arts and crafts & 12,700 & 80.0 & 72.2 & 7.8 & 20.0 & $11.1 !$ & $8.9 !$ & 83.3 \\
\hline Music & 24,900 & 95.6 & 87.9 & $7.7 !$ & $4.4 !$ & $3.5 !$ & $\ddagger$ & 91.4 \\
\hline Dance/drama or theater & 2,500 & $32.1 !$ & $28.2 !$ & $\ddagger$ & 67.9 & 40.1 & $27.8 !$ & 68.3 \\
\hline Health education & 38,600 & 79.7 & 72.9 & 6.9 & 20.3 & 15.0 & 5.3 & 87.8 \\
\hline General elementary education & 61,300 & 77.2 & 51.4 & 25.8 & 22.8 & 11.9 & $10.9 !$ & 63.3 \\
\hline
\end{tabular}

\section{\# Rounds to zero.}

! Interpret data with caution. The standard error for this estimate is equal to 30 percent or more of the estimate's value.

‡ Reporting standards not met. The standard error for this estimate is equal to 50 percent or more of the estimate's value.

NOTE: Teachers include traditional public school and public charter school teachers who taught departmentalized classes to students in any of grades 5-8, and no grades lower than 5 or higher than 9 . Often a main assignment includes several subfields. Under science and social science, several subfields are examined in detail. These subfields are not inclusive of all subfields in the subject and, therefore, do not add to the broad field total. Majors are included regardless of whether they were held within or outside the school/college of education. Majors in main assignment are credited if they were held at the bachelor's degree level or higher. A certification is credited if it is a regular or standard state certificate or a probationary certification in- subject and includes any grades 6 through 8 . Detail may not sum to totals because of rounding and because some data are not shown. Not all apparent differences shown in the table are statistically significant.

SOURCE: U.S. Department of Education, National Center for Education Statistics, Schools and Staffing Survey (SASS), "Public School Teacher Data File," 2011-12.

Source: Baldi, S., Warner-Griffin, C., \& Tadler, C. (2015). Education and Certification Qualifications of Public Middle Grades Teachers of Selected Subjects: Evidence from the 2011-12 Schools and Staffing Survey. NCES 2015-815. National Center for Education Statistics. 


\section{APPENDIX G}

Number of Departmentalized Public High Grades Teachers who Reported a Particular Main Assignment and the Percentage of Teachers who Taught Various Percentages of Classes within that Main Assignment, by Subject of Main Assignment: 2011-12

\begin{tabular}{|c|c|c|c|c|c|c|c|c|}
\hline $\begin{array}{l}\text { Selected main } \\
\text { assignment }\end{array}$ & $\begin{array}{r}\text { Number } \\
\text { of teachers }\end{array}$ & \multicolumn{3}{|c|}{$\begin{array}{l}\text { Percent with a major in } \\
\text { main assignment }\end{array}$} & \multicolumn{3}{|c|}{$\begin{array}{c}\text { Percent with no major in } \\
\text { main assignment }\end{array}$} & $\begin{array}{r}\text { Total } \\
\text { certified }\end{array}$ \\
\hline English & 152,400 & 79.4 & 69.4 & 9.9 & 20.6 & 12.7 & 8.0 & 82.1 \\
\hline Mathematics & 144,800 & 70.1 & 61.5 & 8.7 & 29.9 & 19.4 & 10.4 & 80.9 \\
\hline Physical science & 64,600 & 46.0 & 38.0 & 8.0 & 54.0 & 29.5 & 24.5 & 67.4 \\
\hline Chemistry & 24,200 & 45.9 & 34.2 & 11.8 & 54.1 & 35.6 & 18.4 & 69.8 \\
\hline Earth sciences & 12,400 & 37.9 & 31.8 & $\ddagger$ & 62.1 & 30.8 & 31.3 & 62.5 \\
\hline Physics & 13,300 & 50.4 & 36.7 & $13.7 !$ & 49.6 & 24.1 & 25.5 & 60.8 \\
\hline Government/civics & 15,600 & $6.8 !$ & $\ddagger$ & $5.2 !$ & 93.2 & 19.8 & 73.4 & $21.4 !$ \\
\hline History & 60,300 & 54.8 & 26.0 & 28.8 & 45.2 & 10.9 & 34.4 & 36.9 \\
\hline French & 11,900 & 80.1 & 71.1 & 9.1 & 19.9 & 10.8 & $9.0 !$ & 81.9 \\
\hline German & 3,300 & 85.9 & 73.3 & $\ddagger$ & $14.1 !$ & $\ddagger$ & $\ddagger$ & 83.7 \\
\hline Latin & 1,400 & $54.4 !$ & $48.8 !$ & $\ddagger$ & $45.6 !$ & $43.9 !$ & $\ddagger$ & 92.8 \\
\hline Spanish & 50,500 & 73.7 & 63.3 & 10.4 & 26.3 & 20.7 & 5.6 & 84.0 \\
\hline Art/arts and crafts & 33,400 & 81.9 & 72.3 & $9.6 !$ & 18.1 & 10.2 & 7.9 & 82.5 \\
\hline Music & 38,500 & 93.4 & 87.3 & 6.1 & 6.6 & $4.5 !$ & $2.2 !$ & 91.8 \\
\hline Dance/drama or theater & 10,000 & 73.1 & 52.2 & $\ddagger$ & $26.9 !$ & $19.2 !$ & $7.7 !$ & 71.5 \\
\hline
\end{tabular}

! Interpret data with caution. The standard error for this estimate is between 30 percent and 50 percent of the estimate's value. ₹ Reporting standards not met. The standard error for this estimate is 50 percent more of the estimate's value.

NOTE: Teachers include traditional public school and public charter school teachers who taught departmentalized classes to students in any of grades $10-12$ or grade 9 and no grade lower. Each main assignment includes several subfields. Under science and social science, several subfields are examined in detail. These subfields are not inclusive of all subfields in the subject and, therefore, do not add to the broad field total. Majors are included regardless of whether they were held within or outside the school/college of education. Majors in main assignment are credited if they were held at the bachelor's degree level or higher. A certification is credited if it is a regular or standard state certificate or a probationary in-subject held at the bachelor's degree level or higher. A certification is credited if it is a regular or standard state certificate or a probationary in-subject differences are significant.

Source: Hill, J., \& Stearns, C. (2015). Education and Certification Qualifications of Departmentalized Public High SchoolLevel Teachers of Selected Subjects: Evidence from the 2011-12 Schools and Staffing Survey. NCES 2015-814. National Center for Education Statistics. 